\title{
Applications of Virtual Reality in Engineering and Product Design: Why, What, How, When and Where
}

\author{
Aurora Berni and Yuri Borgianni * \\ Faculty of Science and Technology, Free University of Bozen-Bolzano, 39100 Bolzano, Italy; aurora.berni@unibz.it \\ * Correspondence: yuri.borgianni@unibz.it; Tel.: +39-0471-017821
}

Received: 1 June 2020; Accepted: 29 June 2020; Published: 29 June 2020

check for updates

\begin{abstract}
The research on the use of virtual reality (VR) in the design domain has been conducted in a fragmentary way so far, and some misalignments have emerged among scholars. In particular, the actual support of VR in early design phases and the diffusion of practices involving VR in creative design stages are argued. In the present paper, we reviewed VR applications in design and categorized each of the collected 86 sources into multiple classes. These range from supported design functions to employed VR technologies and the use of systems complementing VR. The identified design functions include not only design activities traditionally supported by VR, such as 3D modelling, virtual prototyping, and product evaluation, but also co-design and design education beyond the early design phases. The possibility to support early design phases by means of VR is mirrored by the attention on products that involve an emotional dimension beyond functional aspects, which are particularly focused on in virtual assemblies and prototypes. Relevant matches between VR technologies and specific design functions have been individuated, although a clear separation between VR devices and supported design tasks cannot be claimed.
\end{abstract}

Keywords: virtual reality; engineering design; product design; industrial design; virtual prototyping; 3D modelling; product evaluation; co-design; early design phases; technological development

\section{Introduction}

Virtual reality (VR) appeared for the first time in the second half of the last century, with Sutherland's head-mounted three-dimensional display [1]. It is possible to individuate four distinct phases in the development of VR technology, based on the reference literature. The main aspects of these periods are summarized in Table 1, which offers an overview of the enhanced capabilities of VR technologies and, correspondingly, their actual benefit to industry and society.

1. The birth of virtual reality technologies was in the late 1960s, where the developed devices were rudimentary and users enjoyed very limited freedom of movement. The first development steps targeted the creation of immersive experiences; however, the resulting scholarly debate about the chances offered by VR was extremely limited in the years that followed the launch of the technology.

2. Major steps to reach technological maturity took place in approximately the 1990s when, simultaneously, several studies and reviews were carried out. In particular, advancements in computing technology and 3D software enabled the evolution of simple CAD models to three-dimensional models integrated in a virtual environment (VE). According to Berta [2], providing a more interactive and immersive visualization of the models boosted the development of VR software and hardware, with consequent increasing interest in this technology. Despite the amount of research, VR was not yet mature enough for extensive applications [3], which gave rise to scholars' misalignments about its actual benefits. Indeed, Adam [4] and Lu et al. [5] claimed that "VR almost works", 
implying that it was not ready to be implemented in real case studies because of it being too expensive for intensive industrial application. On the other hand, other studies revealed that VR and similar technologies were on the verge of larger adoption in industry to improve productivity and to reduce costs [6].

3. After 2000, a more intense exploration phase began, albeit with limitations to large-scale adoption due to the cost and usability of the hardware. In fact, VR reached a sufficient level of maturity for applications in industry and in the engineering field, but its diffusion was still restricted to the experimental environment [7].

4. The last phase is the expansion with full maturity of VR due to the reduction of costs $[8,9]$ that happened after 2010. As a result, this technology not only started being used in the most predictable areas, such as gaming, but it also extensively spread to the medical, military [10], sport [11], educational [12], and astronomical [13] fields, among others.

Table 1. Development phases of virtual reality (VR) technologies, along with characteristic advantages and limitations of the newly introduced versions.

\begin{tabular}{|c|c|c|c|c|c|}
\hline Phase & Time & $\begin{array}{l}\text { Illustrative } \\
\text { System }\end{array}$ & Achievements & Scopes Served & Limitations \\
\hline 1 & 1960s-1980s & $\begin{array}{l}\text { Damocles' } \\
\text { Sword }\end{array}$ & $\begin{array}{c}\text { First } \\
\text { computer-connected } \\
\text { headsets }\end{array}$ & $\begin{array}{l}\text { Engineering } \\
\text { simulations }\end{array}$ & $\begin{array}{l}\text { Limited movement } \\
\text { freedom for the } \\
\text { user }\end{array}$ \\
\hline 2 & $1990 \mathrm{~s}$ & $\begin{array}{l}\text { Cave automatic } \\
\text { virtual } \\
\text { environment } \\
\text { (CAVE) }\end{array}$ & $\begin{array}{l}\text { First immersive } \\
\text { rooms }\end{array}$ & $\begin{array}{l}\text { Extension to } \\
\text { gaming }\end{array}$ & $\begin{array}{l}\text { Bulky, costly, and } \\
\text { uncomfortable } \\
\text { hardware }\end{array}$ \\
\hline 3 & $2000 \mathrm{~s}$ & $\begin{array}{l}\text { SAS Cube } \\
\text { (SAS3) }\end{array}$ & $\begin{array}{l}\text { First PC-based } \\
\text { cubic room; } \\
\text { panoramic views }\end{array}$ & $\begin{array}{l}\text { Experimental } \\
\text { activities; } \\
\text { Internet-based } \\
\text { applications }\end{array}$ & $\begin{array}{l}\text { Usability issues } \\
\text { tackled in a period } \\
\text { featured by wide } \\
\text { exploration of the } \\
\text { technology }\end{array}$ \\
\hline 4 & 2010 s & $\begin{array}{l}\text { HTC Vive, } \\
\text { Oculus Rift }\end{array}$ & $\begin{array}{l}\text { Improved } \\
\text { ergonomics and } \\
\text { significantly } \\
\text { lowered costs }\end{array}$ & $\begin{array}{l}\text { Diffusion and } \\
\text { employment in } \\
\text { many disciplines } \\
\text { and fields of } \\
\text { human activity }\end{array}$ & $\begin{array}{l}\text { Time-consuming } \\
\text { preparation of } \\
\text { projects with } \\
\text { acceptable graphics }\end{array}$ \\
\hline
\end{tabular}

It emerges that the evolution of VR from its first appearance to large-scale involvement in many different fields took place, to a considerable extent, thanks to the introduction of more usable and affordable systems. Companies particularly benefitted from the development and introduction of cheap and handy devices, which encouraged the spread of VR within the design process, too [14]. Nevertheless, the actual uptake and outreach of the use of VR in design-related applications and experiments is still vague, and studies in the field are fragmentary, as can be seen from the background illustrated in Section 2. In this context, the present paper strives to provide a structured landscape of the actual use of VR in design research and its most remarkable aspects.

\section{Background and Objectives}

When it comes to the application of VR in design, the contribution authored by Ottosson [7] can be considered a milestone, ascribable to the VR phase prior to large-scale development. It underlines the necessity to investigate how to implement this technology for real case studies, by outlining VR's potential for supporting a great deal of design activities. In particular, the scholar saw the chance of VR's supporting the initial design phases beside those that are "more naturally" juxtaposed to VR, namely, 3D modeling, virtual prototyping for simulation, and product evaluation. 
VR's actual capability of supporting different functions in design, starting from those individuated by Ottosson [7] at the dawn of the third phase, is the main issue dealt with in the present paper. Other contributions ascribable to the third and fourth phases highlight how different design activities can exploit VR's capabilities advantageously.

Some scholars underlined the versatility of VR with respect to different design functions and stressed the importance of implementing VR systems in every phase of the process, using the right software and VR devices in the appropriate design stage [15,16]. On the contrary, others focused more on using VR for particular applications. For instance, Cecil and Kanchanapiboon [17] and Camburn et al. [18] underlined the importance of using VR in the early design phases, where design problems can be better detected through VR, with consequent improvement in the quality of the product and reductions in its development time and cost. Stark et al. [19] and Falcão and Soares [20] stressed the usefulness of VR systems for product evaluation due to the introduction of VR interfaces related to human interaction with virtual prototypes. Zignego and Gemelli [21] emphasized VR's usefulness for simulations while casting doubts on its potential for aesthetic evaluation of the product.

In some of the analyzed articles, scholars considered also the degree of immersion and its use in combination with additional technologies and tools to provide a realistic sense of presence in the virtual design environment. As such, Stark [19] claimed that VR had matured enough to stimulate users' sensory immersion, providing increasingly realistic interaction and experience with a virtual prototype. Conversely, other scholars considered this technology as a complementary tool only, since it needed to be integrated with physical objects and haptic systems to give an acceptable sense of immersion [18,22-24]. In particular, since the sense of touch is an important aspect to be considered when it comes to the $\mathrm{VE}$, using a real object as tactile feedback could enable complete manipulation control in the immersive VE [25].

The above examples show that a comprehensive view of the advantages unlocked by VR in design is still lacking. In many cases, scholars focused on specific functions within design without providing an overall picture. A larger overview can help us to analyze how different design functions are supported by VR and how they can actually benefit from the different degrees of immersion and additional tools. Many of the most recent reviews provided in the literature where VR technology has been analyzed had a different focus or a different aim, as illustrated below.

Rebelo et al. [26] studied VR devices and their corresponding degrees of immersion, but when they analyzed how VR systems can be used in design, they limited their work to user-centered design. Jimeno and Puerta [27], whose contribution is relatively dated, studied VR to understand its importance, benefits, and developments only in combination with CAD and Computer-Aided Manufacturing technologies. Similarly, Berg and Vance [28] limited their attention to decision-making processes in order to empower industry innovation. Although Kovar et al. [29] extended the field of research to other design processes, this took place only in relation to VR's contribution to Industry 4.0. Adenauer et al. [15] investigated more explicitly the potential of VR in design. However, in this paper, virtual prototyping was included in the early conceptual phases, which is questionable since a developed virtual model is usually considered a means for evaluation in other papers. Coburn et al. [30] showed a number of cases in which VR was used to support different design activities, but those were predefined and there was no claim of comprehensiveness.

Hence, a framework is lacking that systematically maps the functions VR actually supports in the design process. Markedly, while some functions and phases have been made explicit in a fragmentary way, no previous contribution has given an overall picture. This leads to the need for an overview of the applications of VR in the various design functions and activities, although those might be plausibly characterized by an uneven distribution. Likewise, an accurate relationship between VR devices and the design phases where they have been used has not been established.

Starting from this context, we aim to map the reasons for the use of VR in design and the activities supported, which will be grouped into VR functions. Along with the verification of the actual growth 
of VR applications in design pushed by VR's maturity, the aspects that follow are of particular interest and worth investigating.

1. The diffusion of VR in design research over the years and in relation to the phases of VR development outlined in Section 1.

2. The distinguishable design functions supported by VR in the design process and, in particular, the extent to which VR is still underexploited in early design phases, as put forward by Coburn et al. [30]. In this respect, a larger number of contributions for a specific design function might indicate higher attention and major usefulness; as such, the degree of research intensity in various design areas will be considered a proxy of VR's maturity, reliability, and benefits, in line with, e.g., [31].

3. The existence of the hypothesized link between design tasks and corresponding VR systems (indicated by their different levels of immersiveness), as suggested in $[15,16]$.

4. The extent to which supporting tools are leveraged in conjunction with VR in design activities, which has been a main source of scholarly misalignment in the present section.

5. The typology of products that are mostly designed when VR is involved, which, in the authors' view, has been not sufficiently focused on in previous review works. This aspect might be relevant because of the opportunity to capture the variety of design and engineering domains in which VR has been applied, which, in line with Section 1, can be considered a proxy of VR's maturity.

In order to address the above points, the methodology adopted by the authors was the gathering of relevant documents showing VR applications in design and the subsequent classification of these contributions according to multiple criteria.

The remainder of the paper is structured as follows. Section 3 describes how the search for documents showing VR applications in design has been carried out, along with selection criteria. Section 4 illustrates classification criteria and corresponding categories. Section 5 presents and discusses the main outcomes of the study in relation to the above bulleted list. Section 6 draws conclusions and indicates the limitations of the present paper.

\section{Gathering of Relevant Sources Describing the Application of Virtual Reality in Design}

According to the above literature gaps and research aims, the present paper is intended to define a comprehensive set of design functions supported by VR thanks to its immersive capabilities. As aforementioned, the investigation was carried out by means of a literature review focused on VR applications in design, which were subsequently characterized through bespoke taxonomies.

The first step was therefore to collect contributions describing the use of VR in the design process. The article search was conducted using Google Scholar between December 2019 and January 2020. Two groups of search terms (below) were used to search the full texts of scientific papers.

- A group of terms ascribable to virtual reality technology, e.g., "Virtual Reality", "VR", "immersive reality", "immersive environment", and "virtual prototyping".

- A group of terms referring to the design domain, e.g., "design", "product development", and "user experience".

At least one term from each group should be present in the papers' text, as better inferable from the illustrative queries included in Figure 1, which shows the process leading to the selection of relevant sources. The consultation of documents emerging by means of each query was interrupted when the gain in terms of the number of new pertinent contributions was very low and additional efforts would have benefitted the present research to a limited extent. The sample was also extended through a snowballing process and with additional articles published after January 2020 thanks to the ongoing monitoring of the most relevant outlets for design research.

Relevant sources were considered those featuring the following characteristics. 
- The documented and unambiguous use of VR technologies; for instance, studies that just cite or theoretically discuss the employment of VR were discarded. In addition, papers were excluded when they claimed to involve immersive VR but, after a careful analysis, the technology was determined to be not immersive.

- Their focus on design; here, the term "design" encompasses those product development activities described in established descriptions of design processes [32], along with their management and scientific/academic divulgation. Therefore, the mere use of VR in industry, e.g., the enhanced visualization of manufacturing facilities by means of VR, was not considered a sufficient inclusion criterion, as no design-related activity was actually supported. Markedly, this led us to select relevant contributions within the domain of engineering and product design, which represent the backbone of design fields according to the framework by Dykes et al. [33]. More specifically, the field of research was limited to what can be creatively designed and subsequently manufactured. For instance, while novel decorative architectural elements were considered relevant, this did not apply to the organization of environments, spaces, or the arrangement of standard furniture parts in rooms. These inclusion/exclusion criteria favored the subsequent classification of product typology undergoing design supported by VR.

The final sample of relevant contributions consisted of 86 sources, as shown at the bottom of the PRISMA diagram in Figure 1. The gathered 86 documents represent the reference literature on which the subsequent steps of the study were articulated. The list of selected sources can be found in the next section along with a detailed description of the applied classifications.

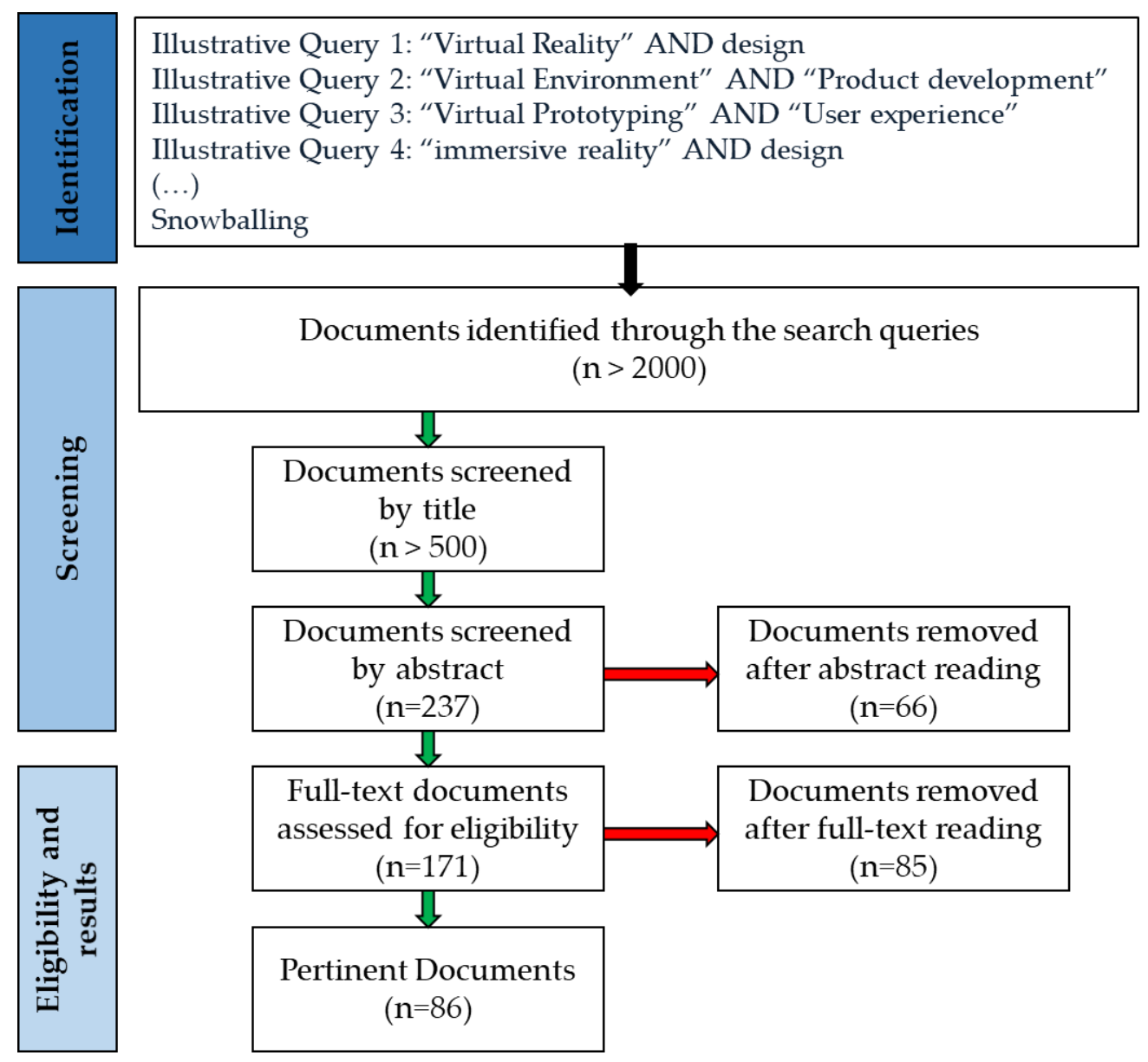

Figure 1. PRISMA diagram showing the selection process of relevant documents describing VR applications in design. 


\section{Materials and Methods}

We classified the selected contributions where VR was implemented for design purposes according to the following criteria, which will be described in detail in the following subsections.

- The design functions supported by VR technologies.

- The involved VR technologies.

- The presence of supporting tools or complementary technologies.

- The categories of people who use VR in the experiment.

- The typology of products designed in the experiments.

- Whether VR technology is compared to traditional design tools.

\subsection{Design Functions Supported by VR Technologies}

Section 2 highlighted inconsistencies concerning the role and the effectiveness of the use of VR in the design process. Many scholars focused on one phase or one specific aspect of the design process only. Indeed, some of them stress that VR has a higher impact in the early design phases [17], while others claim that this immersive technology is better used for product evaluation due to its immersive capabilities [20]. In order to have a whole picture of the potential of VR in design, we considered the design process as a whole and identified six design scopes and functions, designated macro-categories in Table 2. Table 2 includes a description of each macro-category in terms of the specific design activities or objectives that are targeted. The present classification was developed in an inductive way based on the contents of the gathered contributions; this, as opposed to predefined taxonomies, aims to better address the need for comprehensiveness of the classes in terms of the rationales behind the use of VR in design.

Here and in the following, text in italics in the tables indicates shortened versions of the classes' names that are then used in Sections 4.6 and 5 to name them. This measure aims to make subsequent tables and figures more compact and legible.

Table 2. Macro-categories of the functions supported by VR technologies.

\begin{tabular}{|c|c|}
\hline Macro-Categories & Sub-Categories and Design Activities Included \\
\hline 1. Early phases & $\begin{array}{l}\text { Creative design phases (mainly supported through virtual } \\
\text { sketching), individual brainstorming, concept development }\end{array}$ \\
\hline 2. Co-design & $\begin{array}{l}\text { Group brainstorming, collaboration in the simulations, } \\
\text { assessment and re-design of a project, sharing models and data }\end{array}$ \\
\hline 3. $3 D$ modelling & $\begin{array}{l}\text { Virtual clay modeling, detailed/concept immersive } \\
\text { sketching/geometric manipulation and visualization }\end{array}$ \\
\hline $\begin{array}{l}\text { 4. Virtual assembly and prototyping, mechanical } \\
\text { simulation, finite element method (FEM) }\end{array}$ & $\begin{array}{c}\text { Control operations and simulations to verify whether the design } \\
\text { and the assembly/disassembly of the parts work, finite element } \\
\text { analysis, 3D human model simulations and ergonomic } \\
\text { evaluations }\end{array}$ \\
\hline 5. Product Evaluation & $\begin{array}{l}\text { Evaluation of the virtual prototype, gathering of users' feedback } \\
\text { (reactions and experience/preferences of product variants) }\end{array}$ \\
\hline 6. Educational purposes & $\begin{array}{l}\text { Supporting the learning process of students dealing with design } \\
\text { issues }\end{array}$ \\
\hline
\end{tabular}

\subsection{VR Technologies Involved}

The necessity to map employed VR devices emerged in Section 2; here, the level of immersiveness featured by VR technologies might represent a critical factor to benefit design. More specifically, since VR technologies are very heterogeneous, their usability and the degree of the sense of immersion and presence could affect the user during the virtual experience. Therefore, it is likely that these factors could play a fundamental role in the effective application of this technology in the design process. As such, the gathered VR applications were classified according to categories of VR devices. 
In this subsection, we refer only to those devices for the visualization of the VE. Any support tools for interaction with virtual prototypes are described in Section 4.3.

Markedly, three reference types of VR technologies have been identified and considered here for the selection and subsequent classification of VR applications, i.e., head-mounted displays (HMD), the CAVE system or similar devices, and Desktop VR with stereo glasses for 3D visualization. These technologies involve the use of different devices that enable immersion (although to different degrees), in line with Rebelo's [26] taxonomy of VR systems, which we benefitted from.

Table 3 summarizes the three main technologies taken into account and indicated as macro-categories; each of them is accompanied by a description of the devices that are ascribable to the reference technologies. In some contributions, the used VR technology was not inferable (unspecified VR system), and other devices have been individuated that cannot be reconsidered within the three reference technologies.

Table 3. Categories of VR technologies involved.

\begin{tabular}{|c|c|}
\hline $\begin{array}{l}\text { Technology Used for } \\
\text { Visualization }\end{array}$ & Devices \\
\hline Head-mounted displays $(H M D)$ & $\begin{array}{c}\text { Oculus Rift, HTC Vive (Headset }+ \text { controllers) or similar, TiciPrep/TiciView (Headset), } \\
\text { Microsoft }^{\mathrm{TM}} \text { Hololens }{ }^{\mathrm{TM}}\end{array}$ \\
\hline$C A V E$ or similar & $\begin{array}{l}\text { CAVE system and other technologies which involve a large field of view and 3D } \\
\text { glasses for visualization, Cyviz (rear-projected wall display) }\end{array}$ \\
\hline Desktop VR with stereo glasses & Desktop VR with stereoscopic glasses for a three-dimensional view \\
\hline Unspecified VR system & Unknown/ unspecified VR system and adopted devices for mixed reality mock-ups \\
\hline Other & $\begin{array}{c}\text { OpenRT (Open Ray-Trace) techniques, AutoEval interface, two stereo, VirDe, } \\
\text { stereoscopic screen with collocated motion parallax which renders the visual } \\
\text { experience logical and realistic, V.R.A.D.U., WorldViz VR devices, Photographed VRs, } \\
\text { Ramsis system, SATIN system }\end{array}$ \\
\hline
\end{tabular}

\subsection{Presence of Supporting Tools}

Many papers integrated the visualization hardware with interaction hardware to allow the participants of the studies to interact with and modify the model in the VE. As aforementioned, these integrated devices are actually deemed crucial for VR's effectiveness in design, as highlighted in several contributions $[18,22,23,25]$. We classified the supporting tools based on the senses that are stimulated and the level of interactivity provided. For instance, the sense of touch can be stimulated in different ways, but while the user can manipulate the virtual model in a more natural way with interaction gloves, haptics systems provide more conscious and precise interaction with the same model.

A specific class of supporting tools is that of biometric instruments, which are increasingly used in design research [34]. Actually, although they do not stimulate immersiveness and interaction in $\mathrm{VR}$, the latter is monitored through unintended and inadvertent human reactions and behavior, and, as such, the experiments leveraging VR might provide more insightful data.

Table 4 summarizes all the main classes of supporting tools and indicates illustrative devices for each category.

\subsection{Typology of Products Designed in the Experiments}

As aforementioned, the research field was restricted to product, industrial, and engineering design. As these umbrella fields largely overlap and their distinction was not deemed viable in the present case, a bespoke classification was inductively developed to characterize products in terms of the main benefits they engender. Specifically, the functional or emotional orientation of products was considered. Markedly, the products undergoing VR experiments were divided into nonfunctional products and exhibits, industrial products, mechanical products, and vehicles. Although vehicles could be largely included in the mechanical products, they are considered separately here because of the large number of examples in this field and the non-negligible emotional dimension that features 
this domain. The purpose of this categorization was to investigate whether there are products where the use of VR in the design process plays a major role.

Table 4. Categories of VR supporting tools for interaction with a 3D model in the virtual environment.

\begin{tabular}{|c|c|}
\hline Supporting Tools for Interaction & Devices \\
\hline Hands controller & $\begin{array}{l}\text { HTC Vive hands controllers, FlyStick (a 3D pen), Virtual pencil, Wii remote, pliers } \\
\text { tool, two-handed Bezier tool, stylus, wand }\end{array}$ \\
\hline Interaction gloves & CyberGlove, Pinch gloves, Mattel PowerGlove TM, Immersion CyberTouch \\
\hline Sound inputs and/or outputs & Voice recognition, audio output, stereo speakers \\
\hline Haptic systems (haptics) & $\begin{array}{l}\text { Phantom haptic force devices, free force haptic systems, tactile feedback, haptic } \\
\text { feedbacks in general, 3D mouse, spaceball mouse, real objects (e.g., chairs or } \\
\text { steering wheels, pedals, vibrating elements in driver's seat), VirtuoseTM6D35-45 } \\
\text { haptic device }\end{array}$ \\
\hline Motion tracking devices & Head motion tracker/hand motion tracker, head-repositioning device, leap motion \\
\hline Traditional control devices & Keyboard, mouse, joysticks, gamepads, touch screens \\
\hline Biometric instruments & Eye Tracking, Galvanic Skin Response, OptiTrack optical tracking system \\
\hline None/unspecified & No supporter device was used \\
\hline Other & Projector, spherical mirrors, spherical screen, digital tablet, and drawing support \\
\hline
\end{tabular}

Table 5 illustrates the criteria used to include the designed products in the corresponding classes.

Table 5. Categories of designed products.

\begin{tabular}{cc}
\hline Products & What Was Included \\
\hline Nonfunctional products and exhibits & Consumer goods with a predominant aesthetic dimension \\
\hline Industrial products & Consumer goods with relevant aesthetic and functional dimensions \\
\hline Mechanical products & Machines, mechanical systems, and functional products with \\
negligible aesthetic dimensions
\end{tabular}

\subsection{Comparison of VR Technologies to Traditional Design Tools}

To provide a comprehensive view of the effectiveness of VR in design, we indicated all those papers that described a comparison between traditional design tools and VR systems. This aspect is potentially useful for future studies where VR's actual effectiveness in design will be verified beyond its uptake, but it is not analyzed further in the present paper.

\subsection{List of Gathered Contributions and Classification Thereof}

The complete list of gathered sources of VR applications in design is presented in Table 6, along with the categories assigned with reference to the above classes. Unsurprisingly, each contribution might be associated with more entries in virtually any of the considered classes, e.g., an application in which more design activities are supported. All these cases include the sign " $\&$ " in the corresponding cell of Table 6. In addition to the classes described in Sections 4.1-4.5, we have indicated the publication periods of the gathered contributions, which is relevant for the research questions posed in Section 2. 
Table 6. Complete list of references illustrating VR applications in design.

\begin{tabular}{|c|c|c|c|c|c|c|c|}
\hline Source & Year & Country & Design Function & VR Technology & Supporting Tools & Product Category & $\begin{array}{c}\text { Comparison to } \\
\text { Traditional } \\
\text { Design Tools }\end{array}$ \\
\hline Butterworth et al. [35] & 1992 & USA & 3D Modelling & HMD & Traditional control & Nonfunctional & \\
\hline Kameyama [36] & 1997 & Japan & 3D Modelling & Desktop VR & Haptics & Mechanical & \\
\hline Dani and Gadh [37] & 1997 & USA & 3D Modelling & Desktop VR & Gloves \& Sound & Nonfunctional & \\
\hline Jayaram et al. [38] & 1997 & USA & Virtual Prototyping & HMD & $\begin{array}{l}\text { Motion tracking \& } \\
\text { Gloves \& Haptics }\end{array}$ & Mechanical & \\
\hline Lehner and DeFanti [39] & 1997 & USA & $\begin{array}{l}\text { Co-design \& Virtual } \\
\text { Prototyping }\end{array}$ & CAVE & $\begin{array}{l}\text { Hands controller \& } \\
\text { Motion tracking }\end{array}$ & Vehicles & \\
\hline Yeh and Vance [40] & 1998 & USA & Virtual Prototyping & HMD & Gloves & Mechanical & \\
\hline Purschke et al. [41] & 1998 & Germany & $\begin{array}{l}\text { 3D Modelling \& Virtual } \\
\text { Prototyping }\end{array}$ & Other & None/unspecified & Vehicles & \\
\hline Evans et al. [42] & 1999 & USA & Evaluation & Desktop VR & Gloves & Mechanical & $\mathrm{x}$ \\
\hline Jayaram et al. [43] & 1999 & USA & Virtual Prototyping & HMD & $\begin{array}{l}\text { Motion tracking \& } \\
\text { Gloves \& Haptics }\end{array}$ & Mechanical & \\
\hline De sa and Zachmann [44] & 1999 & Germany & Virtual Prototyping & HMD & Sound \& Gloves & Vehicles & \\
\hline Achten et al. [45] & 2000 & The Netherlands & $\begin{array}{l}\text { Education \& 3D } \\
\text { Modelling }\end{array}$ & Unspecified & None/unspecified & Nonfunctional & \\
\hline Ryken and Vance [46] & 2000 & USA & Virtual Prototyping & CAVE & $\begin{array}{l}\text { Hands controller \& } \\
\text { Gloves }\end{array}$ & Mechanical & \\
\hline $\begin{array}{c}\text { Impelluso and } \\
\text { Metoyer-Guidry [47] }\end{array}$ & 2001 & USA & Education & Desktop VR & Traditional control & Mechanical & \\
\hline Kraal and Vance [48] & 2001 & USA & 3D Modelling & HMD \& Desktop VR & $\begin{array}{c}\text { Traditional control \& } \\
\text { Gloves }\end{array}$ & Mechanical & \\
\hline Fiorentino et al. [49] & 2002 & Italy & Early phases & Desktop VR & None/unspecified & Vehicles & \\
\hline Wickman and Söderberg [50] & 2003 & Sweden & $\begin{array}{l}\text { Co-design \& Virtual } \\
\text { Prototyping }\end{array}$ & Desktop VR & None/unspecified & Vehicles & \\
\hline Choi and Chan [51] & 2003 & China & Virtual Prototyping & Desktop VR & None/unspecified & Nonfunctional & \\
\hline Mäkelä et al. [52] & 2004 & Finland & Early phases & CAVE & Hands controller & Nonfunctional & \\
\hline Bochenek and Ragusa [53] & 2004 & USA & Co-design & CAVE & $\begin{array}{l}\text { Motion tracking \& } \\
\text { Traditional control }\end{array}$ & Mechanical & $x$ \\
\hline
\end{tabular}


Table 6. Cont.

\begin{tabular}{|c|c|c|c|c|c|c|c|}
\hline Source & Year & Country & Design Function & VR Technology & Supporting Tools & Product Category & $\begin{array}{c}\text { Comparison to } \\
\text { Traditional } \\
\text { Design Tools }\end{array}$ \\
\hline Moreau et al. [54] & 2004 & France & Virtual Prototyping & HMD & Haptics & Vehicles & \\
\hline Choi and Chan [55] & 2004 & China & Virtual Prototyping & Desktop VR & None/unspecified & Nonfunctional & \\
\hline Krause et al. [56] & 2004 & Germany & $\begin{array}{l}\text { Early phases \& 3D } \\
\text { Modelling }\end{array}$ & CAVE & Hands controller & Industrial & \\
\hline Söderman [57] & 2005 & Sweden & Evaluation & CAVE \& HMD & Haptics & Vehicles & \\
\hline Ye et al. [58] & 2006 & UK & $\begin{array}{l}\text { Early phases \& 3D } \\
\text { Modelling }\end{array}$ & Desktop VR & $\begin{array}{l}\text { Haptics \& Traditional } \\
\text { control }\end{array}$ & Nonfunctional & \\
\hline Pappas et al. [59] & 2006 & Greece & $\begin{array}{l}\text { Co-design \& Virtual } \\
\text { Prototyping }\end{array}$ & Unspecified & None/unspecified & Nonfunctional & \\
\hline Schilling et al. [60] & 2006 & Germany & Virtual Prototyping & HMD & Hands controller & $\begin{array}{l}\text { Mechanical \& } \\
\text { Nonfunctional }\end{array}$ & \\
\hline Bordegoni et al. [61] & 2006 & Italy & Co-design \& Evaluation & HMD & $\begin{array}{l}\text { Haptics \& Motion } \\
\text { tracking }\end{array}$ & Industrial & \\
\hline Keefe et al. [62] & 2007 & USA & Early phases & Desktop VR & Haptics & Nonfunctional & \\
\hline Dorta [63] & 2007 & Canada & Early phases & Other & Other & Vehicles & \\
\hline Zhang et al. [64] & 2007 & USA & $\begin{array}{l}\text { Co-design \& 3D } \\
\text { Modelling }\end{array}$ & CAVE & Haptics & Vehicles & \\
\hline Naef and Payne [65] & 2007 & UK & Evaluation & Other & Gloves \& Sound & Industrial & \\
\hline Ye et al. [66] & 2007 & UK & Evaluation & Desktop VR & Haptics & Industrial & \\
\hline Mahdjoub et al. [67] & 2007 & France & Virtual Prototyping & Other & $\begin{array}{l}\text { Motion tracking \& } \\
\text { Sound \& Gloves }\end{array}$ & Mechanical & \\
\hline Choi and Cheung [68] & 2008 & China & Co-design & Desktop VR \& CAVE & None/unspecified & Nonfunctional & \\
\hline Tideman et al. [69] & 2008 & The Netherlands & Evaluation & Unspecified & $\begin{array}{l}\text { Haptics \& Traditional } \\
\text { control }\end{array}$ & Vehicles & \\
\hline Park et al. [70] & 2008 & Korea & Evaluation & HMD \& Desktop VR & Sound & Industrial & \\
\hline $\begin{array}{c}\text { Van Der Voort and Tideman } \\
\text { [71] }\end{array}$ & 2008 & The Netherlands & Evaluation & Unspecified & $\begin{array}{l}\text { Haptics \& Traditional } \\
\text { control }\end{array}$ & Vehicles & \\
\hline Israel et al. [72] & 2009 & Germany & Early phases & CAVE & Hands controller & Industrial & \\
\hline
\end{tabular}


Table 6. Cont.

\begin{tabular}{|c|c|c|c|c|c|c|c|}
\hline Source & Year & Country & Design Function & VR Technology & Supporting Tools & Product Category & $\begin{array}{c}\text { Comparison to } \\
\text { Traditional } \\
\text { Design Tools }\end{array}$ \\
\hline Ingrassia and Cappello [73] & 2009 & Italy & $\begin{array}{l}\text { 3D Modelling \& Virtual } \\
\text { Prototyping }\end{array}$ & Mechanical & Hands controller & Mechanical & \\
\hline Yan et al. [74] & 2009 & China & 3D Modelling & Unspecified & Haptics & Vehicles & \\
\hline Sung et al. [75] & 2009 & UK & Virtual Prototyping & HMD & Gloves & Mechanical & \\
\hline Lanzotti et al. [76] & 2009 & Italy & Evaluation & Unspecified & None/unspecified & Vehicles & \\
\hline Raposo et al. [77] & 2009 & Brazil & Virtual Prototyping & Unspecified & None/unspecified & Mechanical & \\
\hline Bruno et al. [78] & 2009 & Italy & Virtual Prototyping & Unspecified & Traditional control & Mechanical & \\
\hline Chen et al. [79] & 2010 & China & 3D Modelling & Unspecified & Haptics & Nonfunctional & \\
\hline Bordegoni et al. [80] & 2010 & Italy & 3D Modelling & Other & Haptics & Industrial & \\
\hline Wang and Dumont [81] & 2011 & France & Virtual Prototyping & Unspecified & Haptics & Mechanical & \\
\hline Abulrub et al. [82] & 2011 & UK & $\begin{array}{l}\text { Virtual Prototyping \& } \\
\text { Education }\end{array}$ & CAVE & None/unspecified & Mechanical & \\
\hline Noon et al. [83] & 2012 & USA & $\begin{array}{l}\text { Co-design \& 3D } \\
\text { Modelling }\end{array}$ & CAVE & $\begin{array}{c}\text { Sound \& Traditional } \\
\text { control }\end{array}$ & Vehicles & \\
\hline Toma et al. [84] & 2012 & Romania & $\begin{array}{l}\text { 3D Modelling \& Virtual } \\
\text { Prototyping }\end{array}$ & CAVE & $\begin{array}{l}\text { Gloves \& Biometric \& } \\
\text { Sound }\end{array}$ & Mechanical & $\mathrm{x}$ \\
\hline Makris et al. [85] & 2012 & Greece & $\begin{array}{l}\text { Co-design \& Virtual } \\
\text { Prototyping }\end{array}$ & Unspecified & None/unspecified & Vehicles & \\
\hline Lau [86] & 2012 & China & Early phases \& Education & Unspecified & None/unspecified & Nonfunctional & \\
\hline De Araùjo [87] & 2012 & Portugal & $\begin{array}{c}\text { Early phases \& 3D } \\
\text { Modelling }\end{array}$ & Unspecified & $\begin{array}{l}\text { Motion tracking \& } \\
\text { Sound }\end{array}$ & Nonfunctional & \\
\hline Israel et al. [88] & 2013 & Germany & Early phases & CAVE & Hands controller & Nonfunctional & \\
\hline Grajewski et al. [89] & 2013 & Poland & Virtual Prototyping & CAVE & Haptics & Mechanical & \\
\hline Bordegoni and Ferrise [90] & 2013 & Italy & Evaluation & CAVE & Haptics \& Sound & Industrial & \\
\hline De Araùjo [91] & 2013 & Portugal & $\begin{array}{c}\text { Early phases \& 3D } \\
\text { Modelling }\end{array}$ & Unspecified & $\begin{array}{l}\text { Motion tracking \& } \\
\text { Sound }\end{array}$ & Nonfunctional & $\mathrm{x}$ \\
\hline Backhaus et al. [92] & 2014 & Germany & Evaluation & Unspecified & Haptics & Vehicles & \\
\hline
\end{tabular}


Table 6. Cont.

\begin{tabular}{|c|c|c|c|c|c|c|c|}
\hline Source & Year & Country & Design Function & VR Technology & Supporting Tools & Product Category & $\begin{array}{c}\text { Comparison to } \\
\text { Traditional } \\
\text { Design Tools }\end{array}$ \\
\hline Rentzos et al. [93] & 2014 & Greece & Evaluation & HMD & $\begin{array}{l}\text { Gloves \& Motion } \\
\text { tracking }\end{array}$ & Vehicles & \\
\hline Villagrasa et al. [94] & 2014 & Spain & Education & HMD & None/unspecified & Nonfunctional & \\
\hline Marks et al. [95] & 2014 & New Zealand & $\begin{array}{c}\text { Virtual Prototyping \& } \\
\text { Evaluation }\end{array}$ & HMD & $\begin{array}{c}\text { Motion tracking \& } \\
\text { other }\end{array}$ & Vehicles & $\mathrm{x}$ \\
\hline Grajewski et al. [96] & 2015 & Poland & Education & CAVE & None/unspecified & Industrial & \\
\hline Bharathi and Tucker [97] & 2015 & USA & Education & HMD \& Desktop VR & Traditional control & Industrial & \\
\hline Rojas et al. [98] & 2015 & Spain & Evaluation & CAVE & Biometric & Nonfunctional & \\
\hline Zhang et al. [99] & 2015 & China & Evaluation & Unspecified & Motion tracking & Vehicles & \\
\hline Rieuf et al. [100] & 2015 & France & Early phases & Unspecified & $\begin{array}{c}\text { Biometric \& Motion } \\
\text { tracking }\end{array}$ & Nonfunctional & $x$ \\
\hline Freeman et al. [101] & 2016 & USA & 3D Modelling & Unspecified & None/unspecified & Mechanical & \\
\hline Górski et al. [102] & 2016 & Poland & Evaluation & HMD & $\begin{array}{l}\text { Motion tracking \& } \\
\text { Traditional control }\end{array}$ & Vehicles & \\
\hline Kovar et al. [29] & 2016 & Czech Republic & Virtual Prototyping & CAVE & Haptics & Mechanical & \\
\hline Rieuf et al. [103] & 2017 & France & $\begin{array}{c}\text { Early phases \& Virtual } \\
\text { Prototyping }\end{array}$ & Other & $\begin{array}{c}\text { Hands controller \& } \\
\text { Biometric }\end{array}$ & Industrial & \\
\hline Wolfartsberger et al. [104] & 2017 & Austria & Virtual Prototyping & HMD & None/unspecified & Mechanical & \\
\hline Valencia-Romero and [105] & 2017 & USA & Evaluation & HMD & Traditional control & Nonfunctional & \\
\hline Berg and Vance [106] & 2017 & USA & $\begin{array}{l}\text { Co-design \& Virtual } \\
\text { Prototyping }\end{array}$ & CAVE & $\begin{array}{c}\text { Hands controller \& } \\
\text { Biometric }\end{array}$ & Mechanical & \\
\hline Eroglu et al. [107] & 2018 & Germany & Early phases & CAVE & $\begin{array}{l}\text { Motion tracking \& } \\
\text { Hands controller \& } \\
\text { Traditional control }\end{array}$ & Nonfunctional & \\
\hline Guo et al. [108] & 2018 & China & Virtual Prototyping & CAVE & $\begin{array}{l}\text { Motion tracking \& } \\
\text { Traditional control }\end{array}$ & Vehicles & \\
\hline Song et al. [109] & 2018 & New Zealand & Early phases & Unspecified & None/unspecified & Nonfunctional & \\
\hline Rogers et al. [110] & 2018 & Canada & Evaluation & Other & Hands controller & Vehicles & \\
\hline
\end{tabular}


Table 6. Cont

\begin{tabular}{|c|c|c|c|c|c|c|c|}
\hline Source & Year & Country & Design Function & VR Technology & Supporting Tools & Product Category & $\begin{array}{c}\text { Comparison to } \\
\text { Traditional } \\
\text { Design Tools }\end{array}$ \\
\hline Elbert et al. [111] & 2019 & Germany & Evaluation & HMD & Hands controller & Nonfunctional & $\mathrm{x}$ \\
\hline Kato [112] & 2019 & Japan & Evaluation & HMD \& Other & Hands controller & Vehicles & $x$ \\
\hline Jayasekera and Xu [113] & 2019 & New Zealand & Virtual Prototyping & HMD & Motion tracking & Mechanical & \\
\hline Wolfartsberger [23] & 2019 & Austria & Virtual Prototyping & HMD & None/unspecified & Mechanical & \\
\hline Riegler et al. [114] & 2019 & Austria & Evaluation & HMD & $\begin{array}{l}\text { Hands controller \& } \\
\text { Motion tracking \& } \\
\text { Haptics \& Sound }\end{array}$ & Vehicles & \\
\hline Violante et al. [115] & 2019 & Italy & Evaluation & Unspecified & Haptics & Nonfunctional & \\
\hline De Crescenzio et al. [116] & 2019 & Italy & Evaluation & HMD & None/unspecified & Vehicles & \\
\hline Guo et al. [117] & 2020 & China & Virtual Prototyping & CAVE & $\begin{array}{l}\text { Motion tracking \& } \\
\text { Traditional control }\end{array}$ & Mechanical & $\mathrm{x}$ \\
\hline Lukačević et al. [118] & 2020 & Denmark & Virtual Prototyping & HMD & Hands controller & $\begin{array}{l}\text { Mechanical \& } \\
\text { Nonfunctional }\end{array}$ & \\
\hline
\end{tabular}


In addition, the publication year of each contribution was used to individuate the reference decade ascribable to the VR application; in detail, the 1990s (1991-2000), 2000s (2001-2010), and 2010s (2011-2020) can be approximately linked to the second, third, and fourth phases of VR evolution, respectively. Finally, in order to provide information on the geographical areas in which research on VR-supported design applications took place, Table 6 includes a column named "Country". The reported country matches the affiliation of the corresponding author of each contribution; in the case of multiple affiliations, the first one was considered. Figure 2 presents a world map that highlights the number of publications for each country. The geographic distribution of VR-supported design applications was subsequently organized into three different areas, namely, the Americas (USA, Canada and Brazil), Asia-Pacific (China, Japan, South Korea and New Zealand), and Europe (all the other countries exhibiting at least one contribution).

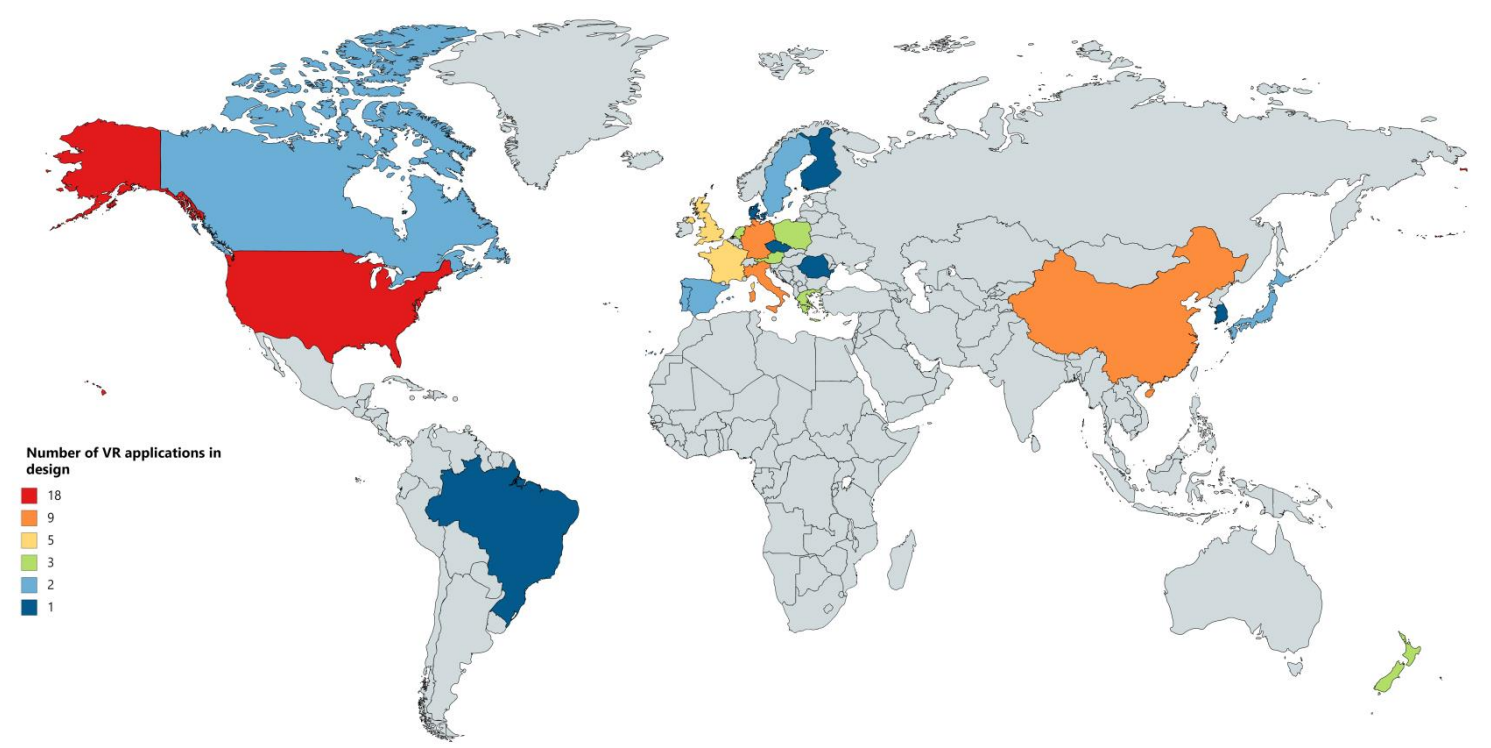

Figure 2. Number of gathered sources describing VR applications in design grouped in terms of the first affiliated country of corresponding authors.

\section{Results and Comments}

The results presented in Table 6 were analyzed in order to gain insight into the issues that supposedly require investigation, as shown in the numbered list in Section 2 . The subsections that follow are also organized based on this numbered list. Each subsection reports on the specific aspect that is taken into consideration.

\subsection{Diffusion of Virtual Reality in Design-Related Applications}

In Figure 3, the number of selected sources per publication year is shown (the year 2020 was not included, as these data could be largely misleading). Figure 3 includes the reference decades and VR development stages. As already mentioned, the intensity of research is considered here as an indicator of the extent of interest in and relevance of a specific topic. Among the 86 gathered sources, 12, 34, and 40 are ascribable to the second (1990s), third (2000s), and fourth (2010s) stages of VR development, respectively (see also Figure 4 on the right-hand side). Therefore, by also considering the anecdotal increase of scientific publications in the last few years, the level of maturity reached by VR in the 2000s can be considered the most critical one for unlocking widespread employment of VR in design research. The number of VR applications in design might also be affected by the simultaneous development and diffusion of competitive systems, e.g., mixed and augmented reality. Thus, a complete picture of the limited expansion of VR use in design might benefit from similar studies in neighboring fields. A different explanation is provided below. 
Indeed, an interesting aspect that can be inferred from Figure 3 is the larger number of contributions found in the final halves of the three considered decades compared to the initial ones. It might be assumed that the technological advancements VR has exhibited have been exploited in design research with a few years' delay. According to this key of reading, the actual number of applications benefitting from the fourth VR development stage should be assessed in the next four to five years.

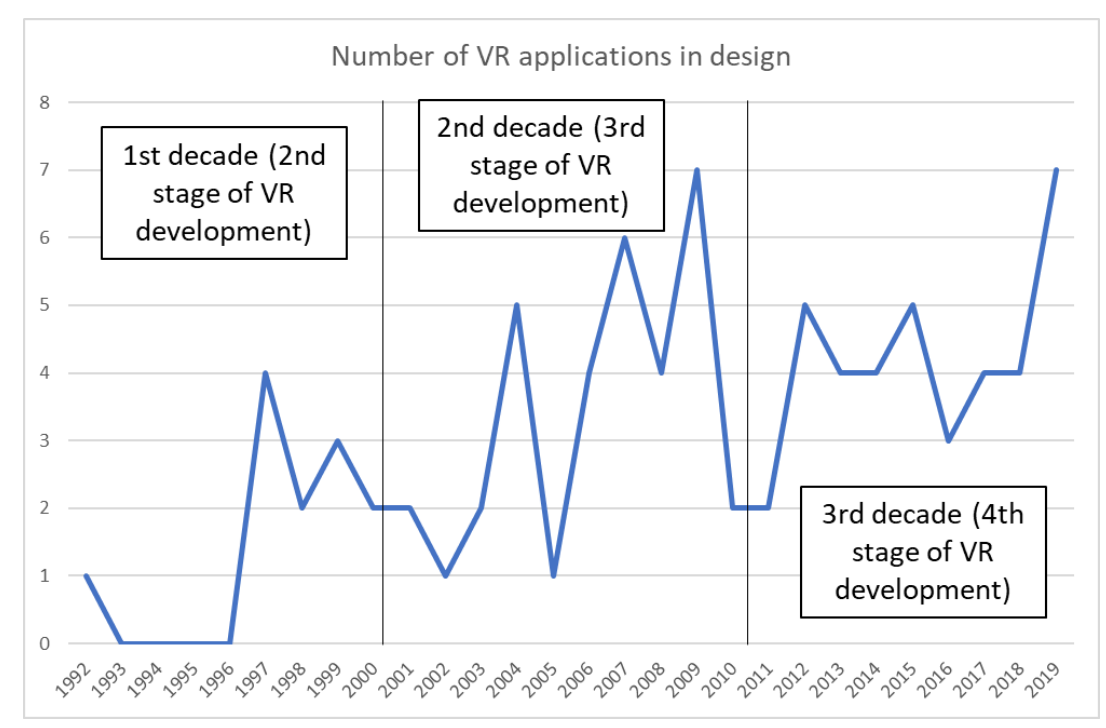

Figure 3. Number of VR applications in design evaluated in terms of the publication years of the reference scientific sources.

The time distribution of the selected contributions across the three continent groups considered here is shown in Figure 4. Interestingly, while the number of contributions has steadily grown in Asia-Pacific and Europe, the interest in VR applications in design has progressively diminished in the Americas. Despite the USA being overall the most prolific country within the collected sources, the overwhelming majority of contributions came from Europe (50 out of 86 ) if the continental instead of national scale is considered.

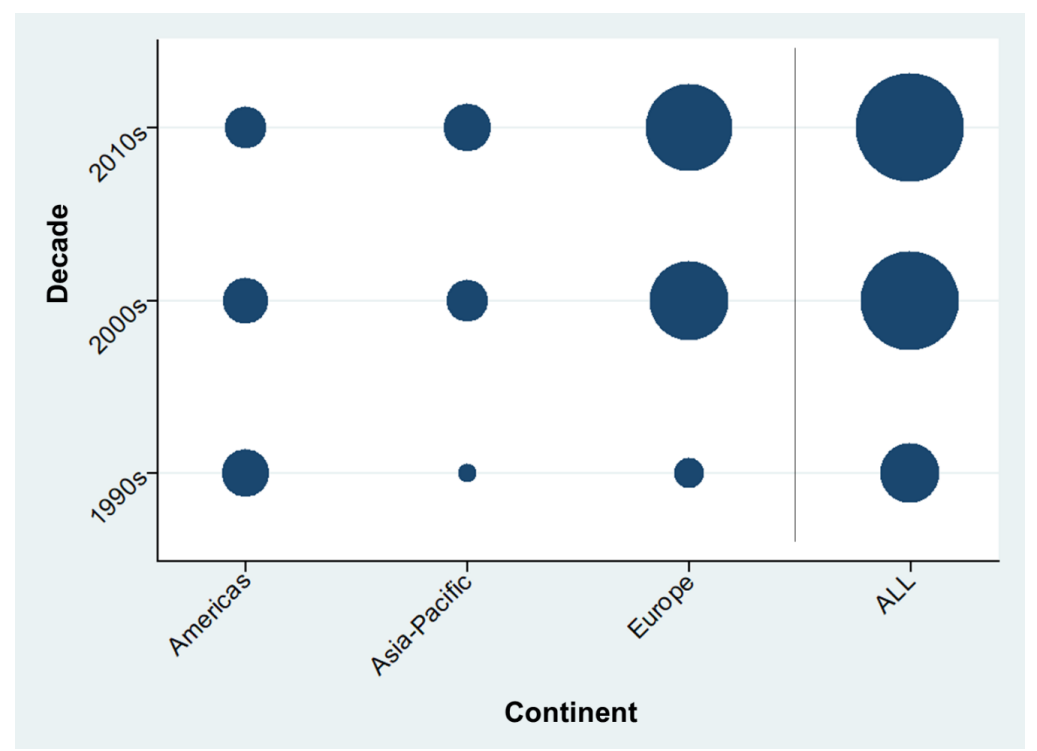

Figure 4. Historic and geographic distribution of the collected sources describing VR applications in design. 


\subsection{Design Functions Supported by Virtual Reality}

The indications from seminal and mature studies on the uptake of VR in design $[7,30]$ have well addressed the main areas for the use of these technologies. Based on the design functions and scopes classified in Section 4.1, the distinguishable design stages that have shown support by VR technologies are actually early phases (15 identified applications), 3D modelling (18), virtual prototyping (32), and product evaluation (23). However, the sole indication of design phase overlooks the presence of scopes of VR employment that are disentangled from different stages of product development. In this respect, we individuated practices using VR as a facilitator of participatory design activities (co-design, 10 identified applications) and as a means to favor education in design (7).

The distribution of sources dealing with the whole set of design functions across the different decades is illustrated in Figure 5, where the sizes of bubbles indicate the number of VR applications.

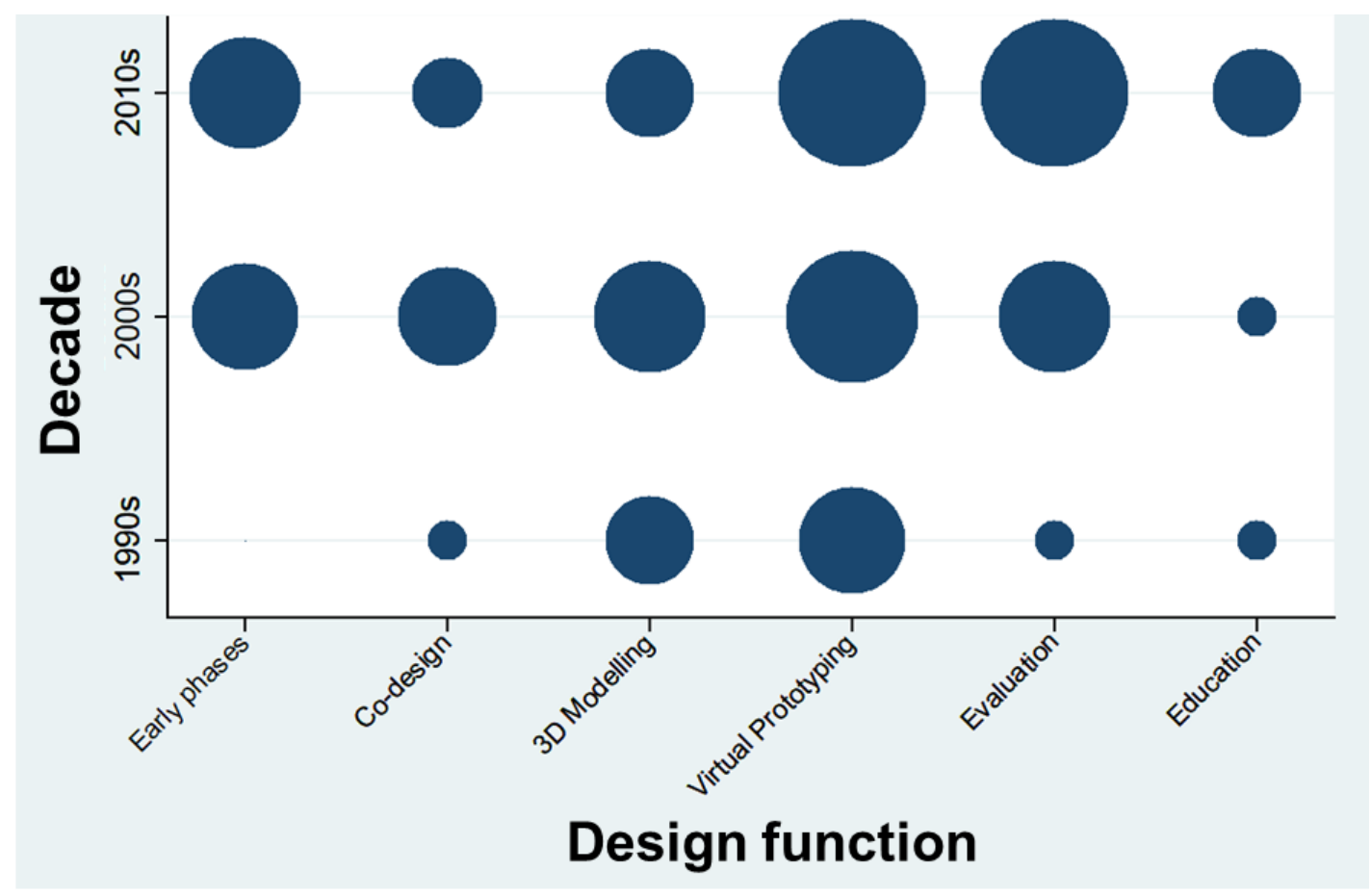

Figure 5. Number of sources illustrating specific design functions that are explicitly supported by VR technologies distributed among the last three decades.

The figures show that 3D modelling and virtual prototyping, i.e., those design phases that follow conceptual stages, were actually the first areas of interest for VR applications in design. While the former has gradually lost its relevance over the years, the latter seems to gain traction increasingly. However, the design function that shows the steadiest growth in interest is seemingly product evaluation, which might have benefitted from enhanced interaction systems to the largest extent. While several contributions assert that the potential of VR support in early design phases has been largely overlooked, the data confirm this claim if just the first decade is considered. Indeed, the number of VR applications targeting initial and creative design activities is comparable with mainstream design functions from the 2000s onwards. As for the originally identified design functions supported by VR, while co-design seems to have attracted particular interest in just the 2000s, a non-negligible number of VR applications targeting educational purposes is observed in just the last decade.

\subsection{Design Functions Supported by Specific Virtual Reality Devices}

The specific VR technology used in design applications could not be determined from the text of the gathered sources in 20 cases out of 86 . Differently, 8 sources showed the use of VR devices that 
cannot be ascribed to any of the three main technologies, i.e., HMD (26 applications), Desktop VR (15), and CAVE (22). Figure 6 shows how the utilization of VR devices was distributed across the previously discussed design functions.

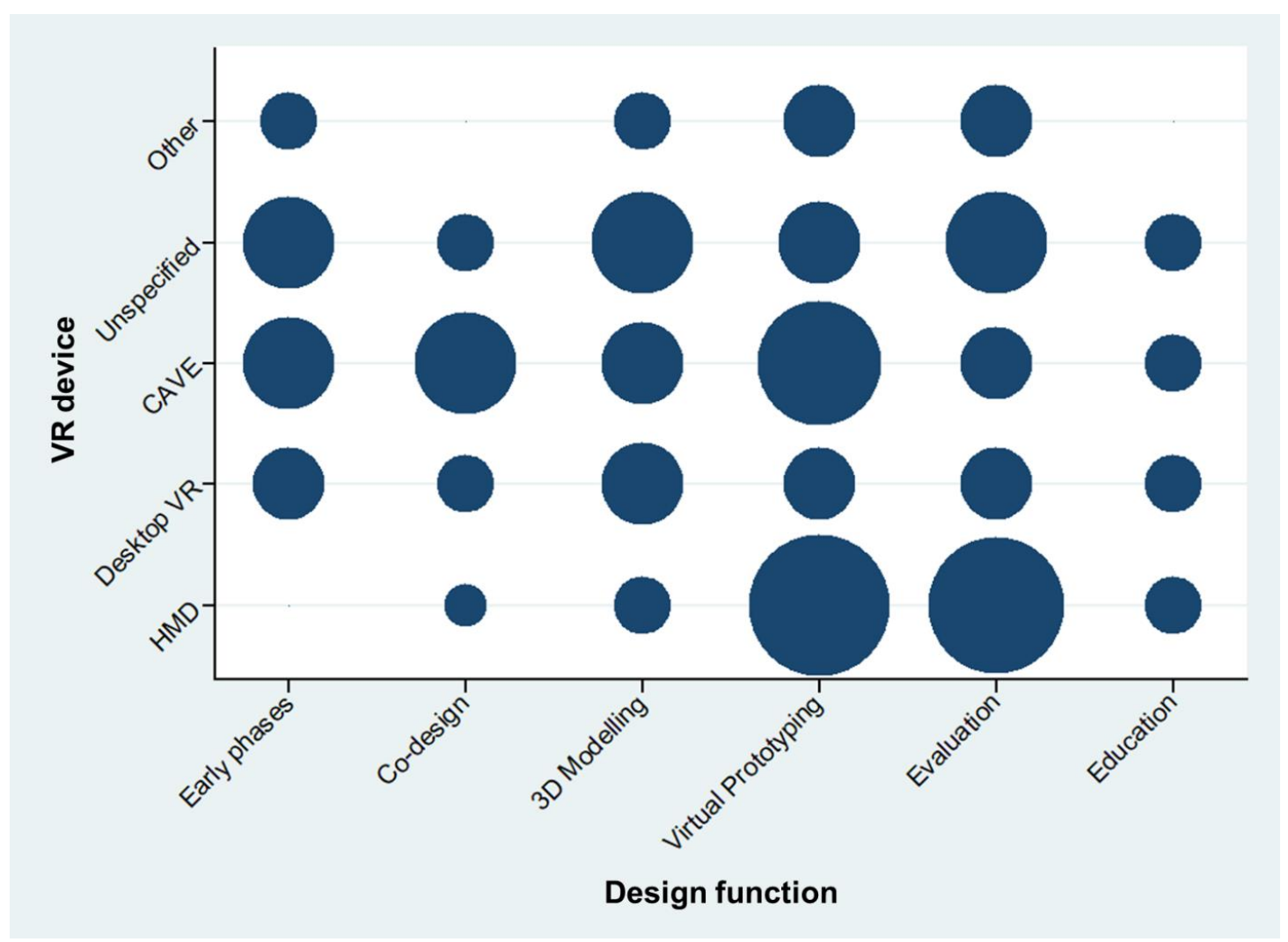

Figure 6. Distribution of the number of applications of specific VR technologies supporting specific design functions.

The figure shows that HMD is seemingly unsuitable to support early design phases, as opposed to virtual prototyping and product evaluation. Early phases seem to have benefitted from the introduction of Desktop VR and systems involving the CAVE technology or alike. The latter proves to be particularly appropriate for co-design activities and virtual prototyping. 3D modelling and, even more markedly, design education tasks appear as those functions showing the most balanced distribution of the three mainstream technologies to support them. As these observations partially back up the relation between specific VR technologies and supported design functions, we tested the actual distribution against a random distribution (VR devices vs. design functions) through a $\chi^{2}$ test. Applications where the employed VR technology was unspecified were excluded. The extracted $p$-value of the $\chi^{2}$ test $(0.130)$ does not allow ruling out that the distribution is random, and, as a result, the relation between design functions and VR technologies requires further investigation. This conclusion is based on the rule of thumb of setting a $p$-value of 0.05 as the threshold for significance, which was complied with here and in the following.

\subsection{Supporting Tools Involved in VR Applications in Design}

The number of examined studies in which supplementary tools did not emerge or were not present in the application of VR technologies in design is 20, which equals the quantity of cases in which specific VR devices could not be identified. This supports the stance of those scholars who claim the relevance of supporting tools and additional functionalities in the use of VR devices. The specific number of peculiar supplementary tools or exploited VR-integrated functionalities is reported in Table 7. 
Table 7. Number of design applications in which VR supporting tools were relevant for the specific case study.

\begin{tabular}{cc}
\hline Supporting Tools for Interaction & Number of VR Applications in Design \\
\hline Hands controller & 16 \\
Interaction gloves & 13 \\
Sound inputs and/or outputs & 11 \\
Haptic systems (haptics) & 22 \\
Motion tracking devices & 18 \\
Traditional control devices & 15 \\
Biometric instruments & 5 \\
None/unspecified & 20 \\
Other & 2 \\
\hline
\end{tabular}

Although haptic systems show the largest number of application cases, they cannot be considered largely predominant because different supporting tools are exploited to similar extents to make the user experience more interactive or to achieve better control.

The distributions of supporting tools across design functions and reference VR technologies were extrapolated (see Figure 7).

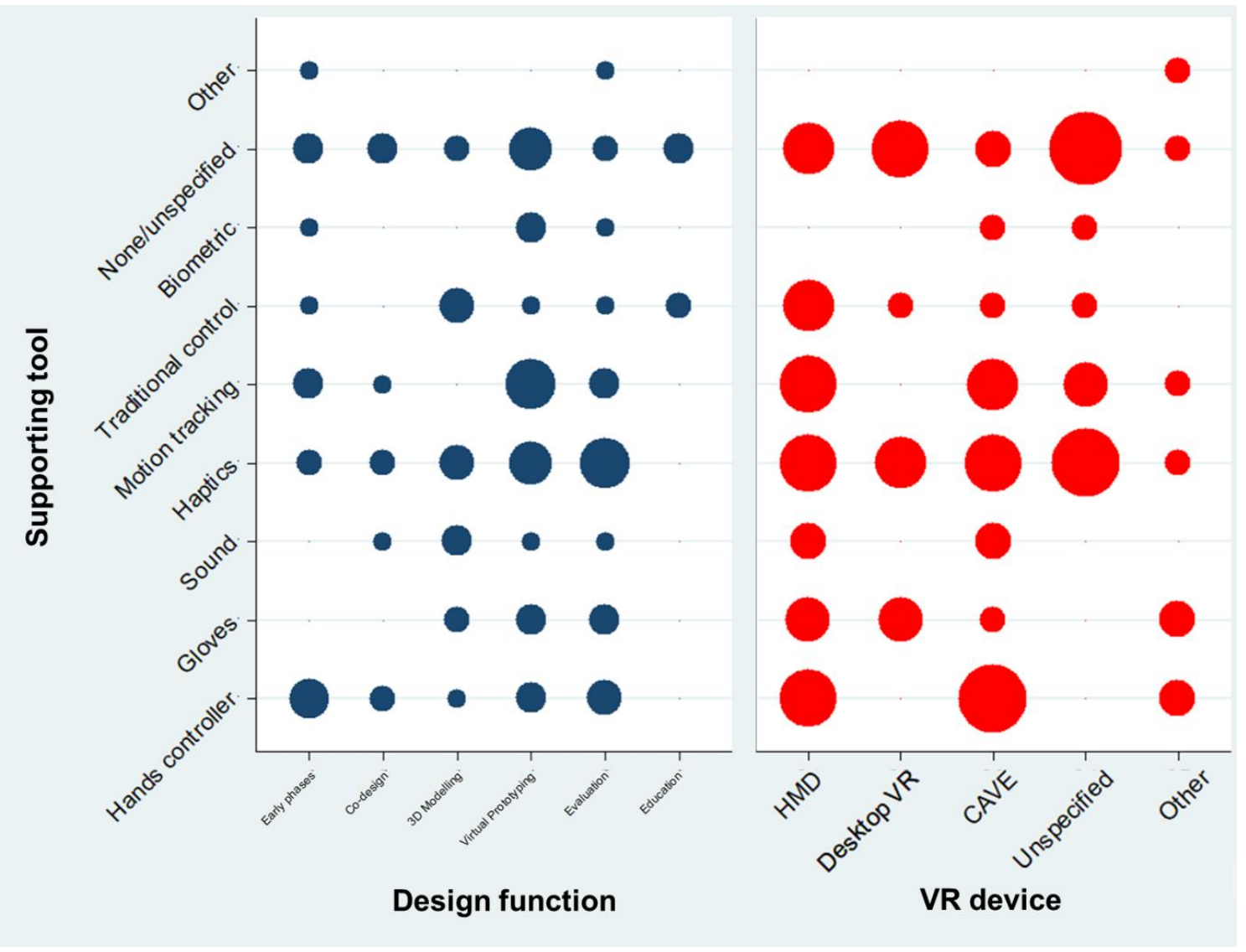

Figure 7. Use of supporting tools in VR applications in design and their distribution against design functions and reference VR technologies.

The two distributions were tested against random distributions through $\chi^{2}$ tests. While the randomness of the former cannot be excluded ( $p=0.113$ ), a solid relation was found between leveraged supporting tools and VR devices $(p=0.046)$. While many combinations of VR devices and supporting tools are possible and plausible, which is backed by the few missing bubbles in the right-hand side of 
Figure 7, it is worth investigating whether the emerging nonrandom relation can be considered to be of general validity or peculiar to design applications.

\subsection{Product Categories Involved in VR Applications in Design}

The study of the typology of products involved in design-related applications of VR laid bare a balance among nonfunctional (25 cases), mechanical (27), and vehicle items (25). Just those products ascribable to industrial design, i.e., those with relevant functional and emotional components in the present study, presented a considerably lower number of applications (11). In addition, this category is the only one that did not undergo any VR experiments before the 2000s, as inferable from Figure 8 , on the left. As this aspect is shared by early design phases, we investigated the distribution of product categories across design functions as well (see Figure 8, on the right).

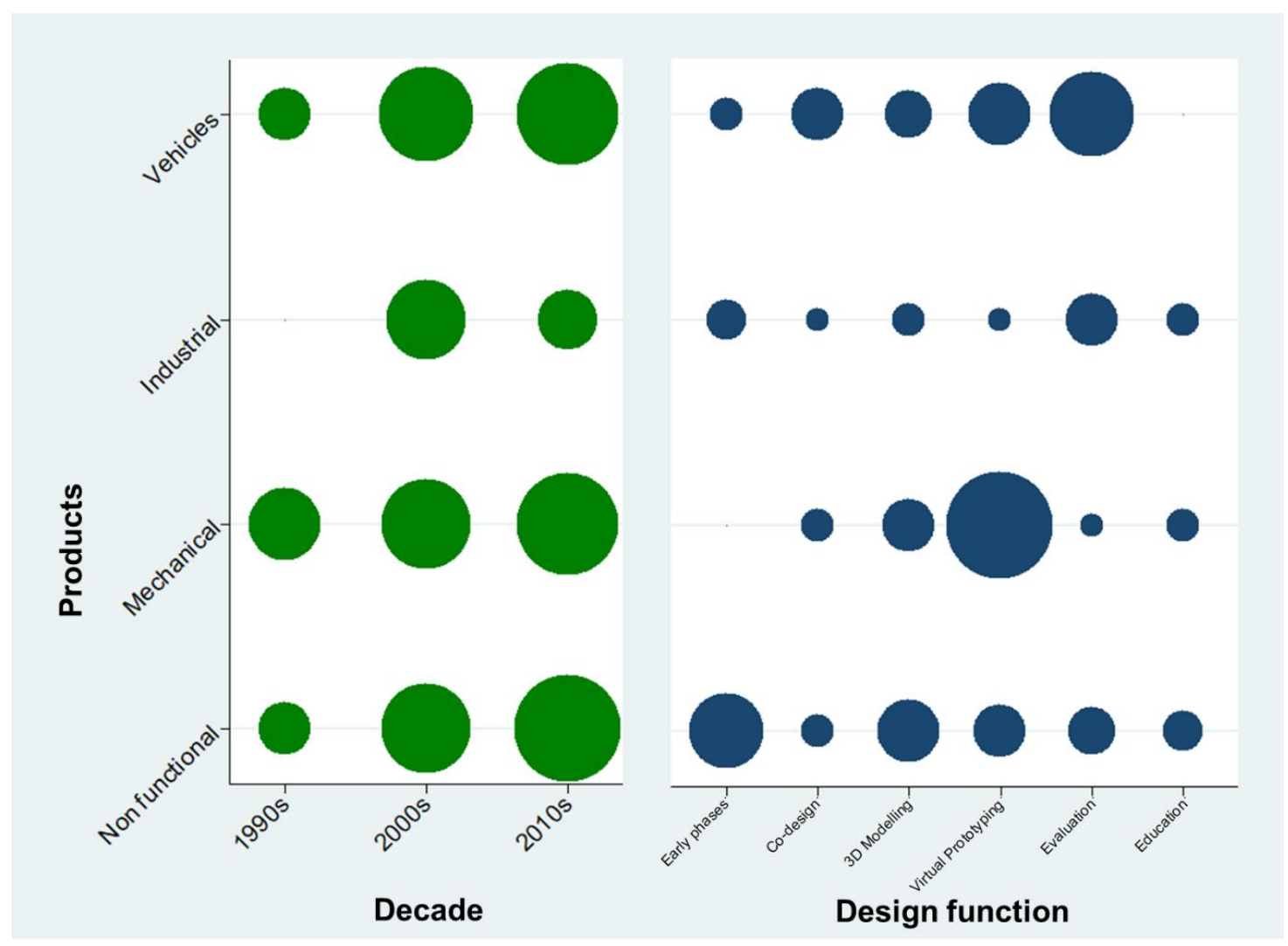

Figure 8. Product categories used in VR applications in design and their distribution across decades and design functions.

The $\chi^{2}$ test of distribution randomness supports a significant match between product categories and involved design functions $(p=0.000)$, although the reasons above cannot be considered as the trigger for such a significant relation. As the reader can observe in Figure 8, early phases involved nonfunctional products to the largest extent, while industrial products underwent VR-supported evaluations in the majority of cases. Particularly relevant matches are also those between virtual prototyping and mechanical products and between product evaluation and vehicles. Also in this case, further investigations would be required to understand the phenomenon fully; more precisely, it is worth studying whether the above relation is peculiar to design overall or just to those applications that involve the use of VR.

Conversely, no significant relation is to be highlighted between product categories and VR development stages, as the $p$-value of the $\chi^{2}$ test is 0.488 . 


\section{Conclusions}

In the present paper, we analyzed a considerable and representative number of sources reporting VR applications in design in order to address some research issues. Although some findings cannot be considered to be conclusive, the main points can be summarized as below.

- While VR was confirmed to be potentially useful in the whole design process, from early to detailed phases and subsequent product evaluation, the benefits of using VR as a tool favoring participatory design and design education have been not specifically focused on hitherto.

- Considerable growth of VR applications in design took place in the 2000s, when Europe superseded the Americas as the leading geographic area with regard to pertinent publications describing said applications.

- The claimed overlooking of the potential of VR in the early design phases can be considered overcome as the maturity of VR technologies has evolved over time.

- Specific VR technologies cannot be considered as being directly ascribable to definite design functions, as a large number of combinations of these two classes were identified. However, the preferential use of certain kinds of devices in specific design circumstances seems inferable from the figures, e.g., the intensive employment of HMD for virtual prototyping and product evaluation.

- Supporting tools have proven relevant for the effective use of VR in design. For instance, haptic systems can be considered established in design-related applications.

- The functional and emotional dimensions of products involved in VR applications in design were studied. Vehicles, which are inherently characterized by both dimensions, represent a relevant share of products in play in these applications, as opposed to other kinds of products traditionally referred to as industrial design. A significant relation was found between categories of products and design functions. However, such a relation could be of general scope and not restricted to VR-supported applications.

The limitations of the paper can be seen in the subjective nature and creation of some classifications, along with subjective exclusion and inclusion of sources describing VR applications in design. The extracted number of case studies, although possibly not comprehensive, is comparable to or exceeds the quantity of sources traditionally analyzed in reviews conducted in the design field or within VR research to infer or fill classifications, e.g., [30,34,119,120].

We based many observations on combinations of different classifications, which were chosen based on emerging issues and the search for some explanatory phenomena. However, not all possible combinations were tested; others can be deemed reasonable, and the presented data lend themselves to further investigations other scholars might be interested in.

Funding: The study is conducted in the frame of the project EYE-TRACK funded by the Free University of Bozen-Bolzano with the call CRC2017. This work was supported by the Open Access Publishing Fund of the Free University of Bozen-Bolzano.

Conflicts of Interest: The authors declare no conflict of interest.

\section{References}

1. Sutherland, I.E. A head-mounted three dimensional display. In Proceedings of the Fall Joint Computer Conference, Fall Joint Computer Conference, Part I, San Francisco, CA, USA, 9-11 December 1968; Association for Computing Machinery: San Francisco, CA, USA, 1968; pp. 757-764.

2. Berta, J. Integrating VR and CAD. IEEE Comput. Graphics Appl. 1999, 19, 14-19. [CrossRef]

3. Bryson, S. Virtual reality in scientific visualization. Comput. Graphics 1993, 17, 679-685. [CrossRef]

4. Adam, J.A. Virtual reality is for real. IEEE Spectr. 1993, 30, 22-29. [CrossRef]

5. Lu, S.C.-Y.; Shpitalni, M.; Gadh, R. Virtual and Augmented Reality Technologies for Product Realization. CIRP Ann. 1999, 48, 471-495. [CrossRef]

6. Brooks, F.P. What's real about virtual reality? IEEE Comput. Graphics Appl. 1999, 19, 16-27. [CrossRef] 
7. Ottosson, S. Virtual reality in the product development process. J. Eng. Des. 2002, 13, 159-172. [CrossRef]

8. Gerschütz, B.; Fechter, M.; Schleich, B.; Wartzack, S. A Review of Requirements and Approaches for Realistic Visual Perception in Virtual Reality. In Proceedings of the Design Society: International Conference on Engineering Design, Delft, The Netherlands, 5-8 August 2019; Cambridge University Press: Cambridge, UK, 2019; Volume 1, pp. 1893-1902. [CrossRef]

9. Huang, F.-C.; Chen, K.; Wetzstein, G. The light field stereoscope: Immersive computer graphics via factored near-eye light field displays with focus cues. ACM Trans. Graph. 2015, 34, 60:1-60:12. [CrossRef]

10. Liu, X.; Zhang, J.; Hou, G.; Wang, Z. Virtual Reality and Its Application in Military. IOP Conf. Ser. Earth Environ. Sci. 2018, 170, 032155. [CrossRef]

11. Yong, L.; Huawei, Z. Simulation assistive technology analysis in volleyball sports based on VR (Virtual Reality). J. Adv. Oxi. Technol. 2018, 21. [CrossRef]

12. Lau, K.W.; Lee, P.Y. The use of virtual reality for creating unusual environmental stimulation to motivate students to explore creative ideas. Interact. Learn. Environ. 2015, 23, 3-18. [CrossRef]

13. West, R.; Johnson, V.; Yeh, I.C.; Thomas, Z.; Tarlton, M.; Mendelowitz, E. Experiencing a slice of the sky: Immersive rendering and sonification of antarctic astronomy data. Electron. Imaging 2018, 3, 449-1-449-10. [CrossRef]

14. Thalen, J.P.; van der Voort, M.C. Facilitating User Involvement in Product Design Through Virtual Reality. In Virtual Reality—Human Computer Interaction; Xinxing, T., Ed.; InTech: London, UK, 2012; ISBN 978-953-51-0721-7.

15. Adenauer, J.; Israel, J.H.; Stark, R. Virtual Reality Technologies for Creative Design. In CIRP Design 2012; Chakrabarti, A., Ed.; Springer: London, UK, 2013; pp. 125-135.

16. Weidlich, D.; Cser, L.; Polzin, T.; Cristiano, D.; Zickner, H. Virtual reality approaches for immersive design. Int. J. Interact. Des. Manuf. 2009, 3, 103-108. [CrossRef]

17. Cecil, J.; Kanchanapiboon, A. Virtual engineering approaches in product and process design. Int. J. Adv. Manuf. Technol. 2007, 31, 846-856. [CrossRef]

18. Camburn, B.; Viswanathan, V.; Linsey, J.; Anderson, D.; Jensen, D.; Crawford, R.; Otto, K.; Wood, K. Design prototyping methods: State of the art in strategies, techniques, and guidelines. Des. Sci. 2017, 3, e13. [CrossRef]

19. Stark, R.; Krause, F.-L.; Kind, C.; Rothenburg, U.; Müller, P.; Hayka, H.; Stöckert, H. Competing in engineering design-The role of Virtual Product Creation. CIRP J. Manuf. Sci. Technol. 2010, 3, 175-184. [CrossRef]

20. Falcão, C.S.; Soares, M.M. Application of Virtual Reality Technologies in Consumer Product Usability. In Proceedings of the Design, User Experience, and Usability. Web, Mobile, and Product Design, Las Vegas, NV, USA, 21-26 July 2013; Marcus, A., Ed.; Springer: Berlin/Heidelberg, Germany, 2013; pp. 342-351.

21. Zignego, M.I.; Gemelli, P. A smart mockup for a small habitat. Int. J. Interact. Des. Manuf. 2019, 1-13. [CrossRef]

22. Petiot, J.-F.; Furet, B. Product, process and industrial system: Innovative research tracks. Int. J. Interact. Des. Manuf. 2010, 4, 211-213. [CrossRef]

23. Wolfartsberger, J. Analyzing the potential of Virtual Reality for engineering design review. Autom. Constr. 2019, 104, 27-37. [CrossRef]

24. Zorriassatine, F.; Wykes, C.; Parkin, R.; Gindy, N. A survey of virtual prototyping techniques for mechanical product development. Proc. Inst. Mech. Eng. Part B J. Eng. Manuf. 2003, 217, 513-530. [CrossRef]

25. Panzoli, D.; Royeres, P.; Fedou, M. Hand-based interactions in Virtual Reality: No better feeling than the real thing! In Proceedings of the 2019 11th International Conference on Virtual Worlds and Games for Serious Applications (VS-Games), Vienna, Austria, 4-6 September 2019; pp. 1-2.

26. Rebelo, F.; Duarte, E.; Noriega, P.; Soares, M.M. Virtual Reality in Consumer Product Design: Methods and Applications. In Human Factors and Ergonomics in Consumer Product Design: Methods and Techniques; Karwowski, W., Soares, M.M., Stanton, N.A., Eds.; Taylor and Francis Group: Boca Raton, FL, USA, 2011; Volume 55, pp. 381-397.

27. Jimeno, A.; Puerta, A. State of the art of the virtual reality applied to design and manufacturing processes. Int. J. Adv. Manuf. Technol. 2007, 33, 866-874. [CrossRef]

28. Berg, L.P.; Vance, J.M. Industry use of virtual reality in product design and manufacturing: A survey. Virtual Real. 2017, 21, 1-17. [CrossRef] 
29. Kovar, J.; Mouralova, K.; Ksica, F.; Kroupa, J.; Andrs, O.; Hadas, Z. Virtual reality in context of Industry 4.0 proposed projects at Brno University of Technology. In Proceedings of the 2016 17th International Conference on Mechatronics-Mechatronika (ME), Prague, Czechia, 7-9 December 2016; pp. 1-7.

30. Coburn, J.Q.; Freeman, I.; Salmon, J.L. A Review of the Capabilities of Current Low-Cost Virtual Reality Technology and Its Potential to Enhance the Design Process. J. Comput. Inf. Sci. Eng. 2017, 17. [CrossRef]

31. Borgianni, Y.; Cascini, G.; Rotini, F. Investigating the future of the fuzzy front end: Towards a change of paradigm in the very early design phases? J. Eng. Des. 2018, 29, 644-664. [CrossRef]

32. Pahl, G.; Beitz, W.; Feldhusen, J.; Grote, K.-H. Engineering Design: A Systematic Approach, 3rd ed.; Springer: London, UK, 2007; ISBN 978-1-84628-318-5.

33. Dykes, T.H.; Rodgers, P.A.; Smyth, M. Towards a new disciplinary framework for contemporary creative design practice. CoDesign 2009, 5, 99-116. [CrossRef]

34. Borgianni, Y.; Maccioni, L. Review of the use of neurophysiological and biometric measures in experimental design research. AI EDAM 2020, 1-38. [CrossRef]

35. Butterworth, J.; Davidson, A.; Hench, S.; Olano, M.T. 3DM: A three dimensional modeler using a head-mounted display. In Proceedings of the 1992 symposium on Interactive 3D graphics-SI3D '92, Cambridge, MA, USA, 29 March-1 April 1992; ACM Press: Cambridge, MA, USA, 1992; pp. 135-138.

36. Kameyama, K. Virtual clay modeling system. In VRST '97: Proceedings of the ACM symposium on Virtual reality software and technology; Thalmann, D., Feiner, S., Singh, G., Eds.; Association for Computing Machinery: New York, NY, USA, 1997; pp. 197-200.

37. Dani, T.H.; Gadh, R. Creation of concept shape designs via a virtual reality interface. Comput. Aided Des. 1997, 29, 555-563. [CrossRef]

38. Jayaram, S.; Connacher, H.I.; Lyons, K.W. Virtual assembly using virtual reality techniques. Comput. Aided Des. 1997, 29, 575-584. [CrossRef]

39. Lehner, V.D.; DeFanti, T.A. Distributed virtual reality: Supporting remote collaboration in vehicle design. IEEE Comput. Graph. Appl. 1997, 17, 13-17. [CrossRef]

40. Yeh, T.P.; Vance, J.M. Applying Virtual Reality Techniques to Sensitivity-Based Structural Shape Design. J. Mech. Des. 1998, 120, 612-619. [CrossRef]

41. Purschke, F.; Schulze, M.; Zimmermann, P. Virtual reality-new methods for improving and accelerating the development process in vehicle styling and design. In Proceedings of the Computer Graphics International (Cat. No.98EX149), Hannover, Germany, 26 June 1998; pp. 789-797.

42. Evans, P.T.; Vance, J.M.; Dark, V.J. Assessing the Effectiveness of Traditional and Virtual Reality Interfaces in Spherical Mechanism Design. J. Mech. Des. 1999, 121, 507-514. [CrossRef]

43. Jayaram, S.; Wang, Y.; Tirumali, H.; Lyons, K.; Hart, P. VADE: A Virtual Assembly Design Environment. IEEE Comput. Grap. Appl. 1999, 19, 44-50. [CrossRef]

44. de Sa, A.G.; Zachmann, G. Virtual reality as a tool for verification of assembly and maintenance processes. Comput. Graph. 1999, 23, 389-403. [CrossRef]

45. Achten, H.; De Vries, B.; Jessurun, J. DDDOOLZ. A Virtual Reality Sketch Tool for Early Design. In Proceedings of the CAADRIA 2000 [Proceedings of the Fifth Conference on Computer Aided Architectural Design Research in Asia], Singapore, 18-19 May 2000; pp. 451-460, ISBN 981-04-2491-4.

46. Ryken, M.J.; Vance, J.M. Applying virtual reality techniques to the interactive stress analysis of a tractor lift arm. Finite Elem. Anal. Des. 2000, 35, 141-155. [CrossRef]

47. Impelluso, T.; Metoyer-Guidry, T. Virtual Reality and Learning by Design: Tools for Integrating Mechanical Engineering Concepts*. J. Eng. Educ. 2001, 90, 527-534. [CrossRef]

48. Kraal, J.C.; Vance, J.M. VEMECS: A virtual reality interface for spherical mechanism design. J. Eng. Des. 2001, 12, 245-254. [CrossRef]

49. Fiorentino, M.; de Amicis, R.; Stork, A.; Monno, G. Surface Design in Virtual Reality as Industrial Application. In Proceedings of the DS 30: Proceedings of DESIGN 2002, the 7th International Design Conference, Dubrovnik, Croatia, 14-17 May 2002; pp. 477-482.

50. Wickman, C.; Söderberg, R. Increased Concurrency between Industrial and Engineering Design Using CAT Technology Combined with Virtual Reality. Concurr. Eng. 2003, 11, 7-15. [CrossRef]

51. Choi, S.H.; Chan, A.M.M. A layer-based virtual prototyping system for product development. Comput. Ind. 2003, 51, 237-256. [CrossRef] 
52. Mäkelä, W.; Reunanen, M.; Takala, T. Possibilities and limitations of immersive free-hand expression: A case study with professional artists. In Proceedings of the 12th Annual ACM, Seattle, WA, USA, 10-16 October 2004; pp. 504-507.

53. Bochenek, G.M.; Ragusa, J.M. Improving Integrated Project Team Interaction Through Virtual (3D) Collaboration. Eng. Manag. J. 2004, 16, 3-12. [CrossRef]

54. Moreau, G.; Fuchs, P.; Stergiopoulos, P. Applications of Virtual Reality in the manufacturing industry: From design review to ergonomic studies. Mech. Ind. 2004, 5, 171-179. [CrossRef]

55. Choi, S.H.; Chan, A.M.M. A virtual prototyping system for rapid product development. Comput. Aided Des. 2004, 36, 401-412. [CrossRef]

56. Krause, F.L.; Göbel, M.; Wesche, G.; Biahmou, T. A Three-Stage Conceptual Design Process Using Virtual Environments. In Proceedings of the 12th International Conference in Central Europe on Computer Graphics, Visualization and Computer Vision'2004, Plzen, Czech Republic, 2-6 February 2004.

57. Söderman, M. Virtual reality in product evaluations with potential customers: An exploratory study comparing virtual reality with conventional product representations. J. Eng. Des. 2005, 16, 311-328. [CrossRef]

58. Ye, J.; Campbell, R.I.; Page, T.; Badni, K.S. An investigation into the implementation of virtual reality technologies in support of conceptual design. Des. Stud. 2006, 27, 77-97. [CrossRef]

59. Pappas, M.; Karabatsou, V.; Mavrikios, D.; Chryssolouris, G. Development of a web-based collaboration platform for manufacturing product and process design evaluation using virtual reality techniques. Int. J. Comput. Integr. Manuf. 2006, 19, 805-814. [CrossRef]

60. Schilling, A.; Kim, S.; Weissmann, D.; Tang, Z.; Choi, S. CAD-VR geometry and meta data synchronization for design review applications. J. Zhejiang Univ. Sci. A 2006, 7, 1482-1491. [CrossRef]

61. Bordegoni, M.; Colombo, G.; Formentini, L. Haptic technologies for the conceptual and validation phases of product design. Comput. Graphics 2006, 30, 377-390. [CrossRef]

62. Keefe, D.; Zeleznik, R.; Laidlaw, D. Drawing on Air: Input Techniques for Controlled 3D Line Illustration. IEEE Trans. Vis. Comput. Graphics 2007, 13, 1067-1081. [CrossRef]

63. Dorta, T. Implementing and assessing the hybrid ideation space: A cognitive artefact for conceptual design. Moon 2007, 14, 16.

64. Zhang, R.; Noon, C.; Winer, E.; Oliver, J.H.; Gilmore, B.; Duncan, J. Immersive Product Configurator for Conceptual Design. Am. Soc. Mech. Eng. Digit. Collect. 2007, 48078, 1403-1413.

65. Naef, M.; Payne, J. AutoEval mkII-Interaction Design for a VR Design Review System. In Proceedings of the 2007 IEEE Symposium on 3D User Interfaces, Charlotte, NC, USA, 10-11 March 2007.

66. Ye, J.; Badiyani, S.; Raja, V.; Schlegel, T. Applications of Virtual Reality in Product Design Evaluation. In Proceedings of the Human-Computer Interaction. HCI Applications and Services, Beijing, China, 22-27 July 2007; Jacko, J.A., Ed.; Springer: Berlin/Heidelberg, Germany, 2007; pp. 1190-1199.

67. Mahdjoub, M.; Gomes, S.; Sagot, J.-C.; Bluntzer, J.-B. Virtual Reality for a Human-Centered Design Methodology. In Proceedings of the 6th Eurosim (Federation of European Simulation Societies) Congress on Modelling and Simulation, Ljubljana, Slovenia, 9-13 September 2007; p. 8.

68. Choi, S.H.; Cheung, H.H. A versatile virtual prototyping system for rapid product development. Comput. Ind. 2008, 59, 477-488. [CrossRef]

69. Tideman, M.; van der Voort, M.C.; van Houten, F.J.A.M. A new product design method based on virtual reality, gaming and scenarios. Int. J. Interact. Des. Manuf. 2008, 2, 195-205. [CrossRef]

70. Park, H.; Son, J.-S.; Lee, K.-H. Design evaluation of digital consumer products using virtual reality-based functional behaviour simulation. J. Eng. Des. 2008, 19, 359-375. [CrossRef]

71. Van Der Voort, M.C.; Tideman, M. Combining scenarios and virtual reality into a new approach to including users in product design processes. J. Des. Res. 2008, 7, 393-410. [CrossRef]

72. Israel, J.H.; Wiese, E.; Mateescu, M.; Zöllner, C.; Stark, R. Investigating three-dimensional sketching for early conceptual design-Results from expert discussions and user studies. Comput. Graphics 2009, 33, 462-473. [CrossRef]

73. Ingrassia, T.; Cappello, F. VirDe: A new virtual reality design approach. Int. J. Interact. Des. Manuf. 2009, 3, 1-11. [CrossRef]

74. Yan, F.X.; Hou, Z.X.; Zhang, D.H.; Kang, W.K. Virtual Clay Modeling System with 6-DOF Haptic Feedback. Mater. Sci. Forum 2009, 628-629, 155-160. [CrossRef] 
75. Sung, R.C.W.; Ritchie, J.M.; Robinson, G.; Day, P.N.; Corney, J.R.; Lim, T. Automated design process modelling and analysis using immersive virtual reality. Comput.-Aided Des. 2009, 41, 1082-1094. [CrossRef]

76. Lanzotti, A.; Di Gironimo, G.; Matrone, G.; Patalano, S.; Renno, F. Virtual concepts and experiments to improve quality of train interiors. Int. J. Interact. Des. Manuf. 2009, 3, 65-79. [CrossRef]

77. Raposo, A.; Santos, I.; Soares, L.; Wagner, G.; Corseuil, E.; Gattass, M. Environ: Integrating VR and CAD in Engineering Projects. IEEE Comput. Graphics Appl. 2009, 29, 91-95. [CrossRef]

78. Bruno, F.; Caruso, F.; Li, K.; Milite, A.; Muzzupappa, M. Dynamic simulation of virtual prototypes in immersive environment. Int. J. Adv. Manuf. Technol. 2009, 43, 620-630. [CrossRef]

79. Chen, L.; Wang, K.Q.; Xu, R.P. The Study of Products Design \& Developement Using Virtual Clay Modeling System. Appl. Mech. Mater. 2010, 44-47, 2101-2105. [CrossRef]

80. Bordegoni, M.; Ferrise, F.; Covarrubias, M.; Antolini, M. Haptic and Sound Interface for Shape Rendering. Presence Teleoper. Virtual Environ. 2010, 19, 341-363. [CrossRef]

81. Wang, Z.; Dumont, G. Haptic manipulation of deformable CAD parts with a two-stage method. Int. J. Interact. Des. Manuf. 2011, 5, 255-270. [CrossRef]

82. Abulrub, A.-H.G.; Attridge, A.N.; Williams, M.A. Virtual reality in engineering education: The future of creative learning. In Proceedings of the 2011 IEEE Global Engineering Education Conference (EDUCON), Amman, Jordan, 4-6 April 2011; pp. 751-757.

83. Noon, C.; Zhang, R.; Winer, E.; Oliver, J.; Gilmore, B.; Duncan, J. A system for rapid creation and assessment of conceptual large vehicle designs using immersive virtual reality. Comput. Ind. 2012, 63, 500-512. [CrossRef]

84. Toma, M.I.; Gîrbacia, F.; Antonya, C. A comparative evaluation of human interaction for design and assembly of 3D CAD models in desktop and immersive environments. Int. J. Interact. Des. Manuf. 2012, 6, 179-193. [CrossRef]

85. Makris, S.; Rentzos, L.; Pintzos, G.; Mavrikios, D.; Chryssolouris, G. Semantic-based taxonomy for immersive product design using VR techniques. CIRP Ann. 2012, 61, 147-150. [CrossRef]

86. Lau, K.W. A study of students' learning experiences in creativity training in design education: An empirical research in virtual reality. J. Des. Res. 2012, 10, 170. [CrossRef]

87. De Araùjo, B.R.; Casiez, G.; Jorge, J.A. Mockup builder: Direct 3D modeling on and above the surface in a continuous interaction space. In Proceedings of the Graphics Interface 2012, Toronto, ON, Canada, 28-30 May 2012; Canadian Information Processing Society: Toronto, ON, Canada, 2012; pp. 173-180.

88. Israel, J.H.; Mauderli, L.; Greslin, L. Mastering digital materiality in immersive modelling. In Proceedings of the International Symposium on Sketch-Based Interfaces and Modeling-SBIM '13, Anaheim, CA, USA, 19-21 July 2013; pp. 15-22.

89. Grajewski, D.; Górski, F.; Zawadzki, P.; Hamrol, A. Application of Virtual Reality Techniques in Design of Ergonomic Manufacturing Workplaces. Procedia Comput. Sci. 2013, 25, 289-301. [CrossRef]

90. Bordegoni, M.; Ferrise, F. Designing interaction with consumer products in a multisensory virtual reality environment. Virtual Phys. Prototyp. 2013, 8, 51-64. [CrossRef]

91. De Araújo, B.R.; Casiez, G.; Jorge, J.A.; Hachet, M. Mockup Builder: 3D modeling on and above the surface. Comput. Graphics 2013, 37, 165-178. [CrossRef]

92. Backhaus, K.; Jasper, J.; Westhoff, K.; Gausemeier, J.; Grafe, M.; Stöcklein, J. Virtual Reality Based Conjoint Analysis for Early Customer Integration in Industrial Product Development. Procedia CIRP 2014, 25, 61-68. [CrossRef]

93. Rentzos, L.; Vourtsis, C.; Mavrikios, D.; Chryssolouris, G. Using VR for Complex Product Design. In Virtual, Augmented and Mixed Reality. Applications of Virtual and Augmented Reality; Shumaker, R., Lackey, S., Eds.; Springer International Publishing: Cham, Switzerland, 2014; pp. 455-464.

94. Villagrasa, S.; Fonseca, D.; Durán, J. Teaching case: Applying gamification techniques and virtual reality for learning building engineering 3D arts. In Proceedings of the TEEM '14: 2nd International Conference on Technological Ecosystems for Enhancing Multiculturality, Salamanca, Spain, 1-3 October 2014; pp. 171-177.

95. Marks, S.; Estevez, J.E.; Connor, A.M. Towards the Holodeck: Fully Immersive Virtual Reality Visualisation of Scientific and Engineering Data. In Proceedings of the Proceedings of the 29th International Conference on Image and Vision Computing New Zealand, Hamilton, New Zealand, 19-21 November 2014; Association for Computing Machinery: Hamilton, New Zealand, 2014; pp. 42-47. 
96. Grajewski, D.; Diakun, J.; Wichniarek, R.; Dostatni, E.; Buń, P.; Górski, F.; Karwasz, A. Improving the Skills and Knowledge of Future Designers in the Field of Ecodesign Using Virtual Reality Technologies. Procedia Comput. Sci. 2015, 75, 348-358. [CrossRef]

97. Bharathi, A.K.B.G.; Tucker, C.S. Investigating the Impact of Interactive Immersive Virtual Reality Environments in Enhancing Task Performance in Online Engineering Design Activities. Am. Soc. Mech. Eng. Digit. Collect. 2015, 57106, V003T04A004.

98. Rojas, J.-C.; Contero, M.; Bartomeu, N.; Guixeres, J. Using Combined Bipolar Semantic Scales and Eye-Tracking Metrics to Compare Consumer Perception of Real and Virtual Bottles: Semantic Scales and Eye-Tracking Metrics to Compare Perception. Packag. Technol. Sci. 2015, 28, 1047-1056. [CrossRef]

99. Zhang, Z.; Peng, Q.; Gu, P. Improvement of User Involvement in Product Design. Procedia CIRP 2015, 36, 267-272. [CrossRef]

100. Rieuf, V.; Bouchard, C.; Aoussat, A. Immersive moodboards, a comparative study of industrial design inspiration material. J. Des. Res. 2015, 13, 78. [CrossRef]

101. Freeman, I.J.; Salmon, J.L.; Coburn, J.Q. CAD Integration in Virtual Reality Design Reviews for Improved Engineering Model Interaction. Am. Soc. Mech. Eng. Digit. Collect. 2016, 50657, V011T15A006.

102. Górski, F.; Buń, P.; Wichniarek, R.; Zawadzki, P.; Hamrol, A. Design and Implementation of a Complex Virtual Reality System for Product Design with Active Participation of End User. In Advances in Human Factors, Software, and Systems Engineering; Górski, F., Buń, P., Wichniarek, R., Zawadzki, P., Hamrol, A., Eds.; Springer International Publishing: Cham, Switzerland, 2016; pp. 31-43.

103. Rieuf, V.; Bouchard, C.; Meyrueis, V.; Omhover, J.-F. Emotional activity in early immersive design: Sketches and moodboards in virtual reality. Des. Stud. 2017, 48, 43-75. [CrossRef]

104. Wolfartsberger, J.; Zenisek, J.; Sievi, C.; Silmbroth, M. A virtual reality supported 3D environment for engineering design review. In Proceedings of the 2017 23rd International Conference on Virtual System Multimedia (VSMM), Dublin, Ireland, 31 October-2 November 2017; pp. 1-8.

105. Valencia-Romero, A.; Lugo, J.E. An immersive virtual discrete choice experiment for elicitation of product aesthetics using Gestalt principles. Des. Sci. 2017, 3, e11. [CrossRef]

106. Berg, L.P.; Vance, J.M. An Industry Case Study: Investigating Early Design Decision Making in Virtual Reality. J. Comput. Inf. Sci. Eng. 2017, 17. [CrossRef]

107. Eroglu, S.; Gebhardt, S.; Schmitz, P.; Rausch, D.; Kuhlen, T.W. Fluid Sketching-Immersive Sketching Based on Fluid Flow. In Proceedings of the 2018 IEEE Conference on Virtual Reality and 3D User Interfaces (VR), Reutlingen, Germany, 18-22 March 2018; pp. 475-482.

108. Guo, Z.; Zhou, D.; Chen, J.; Geng, J.; Lv, C.; Zeng, S. Using virtual reality to support the product's maintainability design: Immersive maintainability verification and evaluation system. Comput. Indust. 2018, 101, 41-50. [CrossRef]

109. Song, H.; Chen, F.; Peng, Q.; Zhang, J.; Gu, P. Improvement of user experience using virtual reality in open-architecture product design. Proc. Inst. Mech. Eng. Part B J. Eng. Manuf. 2018, 232, 2264-2275. [CrossRef]

110. Rogers, J.; Lo, T.T.; Schnabel, M.A. Digital Culture: An Interconnective Design Methodology Ecosystem. In Proceedings of the 23rd International Conference of the Association for Computer-Aided Architectural Design Research in Asia (CAADRIA): Learning, Adapting and Prototyping, Beijing, China, 1 May 2018; Volume 1, pp. 493-502.

111. Elbert, R.; Knigge, J.-K.; Makhlouf, R.; Sarnow, T. Experimental study on user rating of virtual reality applications in manual order picking. IFAC-PapersOnLine 2019, 52, 719-724. [CrossRef]

112. Kato, T. Verification of perception difference between actual space and VR space in car design. Int. J. Interact. Des. Manuf. 2019, 13, 1233-1244. [CrossRef]

113. Jayasekera, R.D.M.D.; Xu, X. Assembly validation in virtual reality-A demonstrative case. Int. J. Adv. Manuf. Technol. 2019, 105, 3579-3592. [CrossRef]

114. Riegler, A.; Riener, A.; Holzmann, C. AutoWSD: Virtual Reality Automated Driving Simulator for Rapid HCI Prototyping. In Proceedings of the MuC'19: Mensch-und-Computer, Hamburg, Germany, 8-11 September 2019; pp. 853-857.

115. Violante, M.G.; Vezzetti, E.; Piazzolla, P. How to design a virtual reality experience that impacts the consumer engagement: The case of the virtual supermarket. Int. J. Interact. Des. Manuf. 2019, 13, 243-262. [CrossRef] 
116. De Crescenzio, F.; Bagassi, S.; Asfaux, S.; Lawson, N. Human centred design and evaluation of cabin interiors for business jet aircraft in virtual reality. Int. J. Interact. Des. Manuf. 2019, 13, 761-772. [CrossRef]

117. Guo, Z.; Zhou, D.; Zhou, Q.; Mei, S.; Zeng, S.; Yu, D.; Chen, J. A hybrid method for evaluation of maintainability towards a design process using virtual reality. Comput. Indust. Eng. 2020, 140, 106227. [CrossRef]

118. Lukačević, F.; Škec, S.; Törlind, P.; Štorga, M. Identifying subassemblies and understanding their functions during a design review in immersive and non-immersive virtual environments. Front. Eng. Manag. 2020. [CrossRef]

119. Colombo, E.F.; Cascini, G.; de Weck, O.L. Classification of Change-Related Ilities Based on a Literature Review of Engineering Changes. J. Integrated Des. Process Sci. 2016, 20, 3-23. [CrossRef]

120. Masoudi, N.; Fadel, G.M.; Pagano, C.C.; Elena, M.V. A Review of Affordances and Affordance-Based Design to Address Usability. In Proceedings of the Design Society: International Conference on Engineering Design, Delft, The Netherlands, 5-8 August 2019; Volume 1, pp. 1353-1362. [CrossRef]

(C) 2020 by the authors. Licensee MDPI, Basel, Switzerland. This article is an open access article distributed under the terms and conditions of the Creative Commons Attribution (CC BY) license (http://creativecommons.org/licenses/by/4.0/). 